\title{
Mechanical properties of austenitic heat-resistant Fe-20Cr-30Ni-2Nb steel at ambient temperature
}

\author{
Naoki Takata*, Naoya Kanno ${ }^{\dagger}$, Masao Takeyama
}

Department of Metallurgy and Ceramics Science, Graduate School of Science and Engineering, Tokyo Institute of Technology, 2-12-1-S8-8, Ookayama, Meguro-ku, Tokyo 152-8552, Japan

* Corresponding author.

Present address: Department of Materials Science and Engineering, Nagoya University, Furo-cho, Chikusa-ku, Nagoya 464-8603 Japan.

E-mail address: takata@numse.nagoya-u.ac.jp (N. Takata).

$\uparrow$ Present address: IHI Corporation

Keywords: austenitic heat-resistant steels; Laves phase; precipitation; ductility; tensile test; Charpy impact test 


\begin{abstract}
The mechanical properties of $\mathrm{Fe}-20 \mathrm{Cr}-30 \mathrm{Ni}-2 \mathrm{Nb}$ (at.\%) steels with controlled microstructures were examined by conducting tensile tests and Charpy impact tests at room temperature. The solution-treated specimen ( $-\mathrm{Fe}$ single-phase) exhibited a yield strength ( $\mathrm{y}$ ) of $210 \mathrm{MPa}$ and a maximum tensile strength ( $\mathrm{UTS}$ ) of $850 \mathrm{MPa}$. Its rupture strain ( $\mathrm{r}$ ) was more than $40 \%$. The specimen with high area fraction of the $\mathrm{Fe}_{2} \mathrm{Nb}$ Laves phase on the grain boundaries ( ) exhibited a higher y of $276 \mathrm{MPa}$ and adequate tensile ductility $(\mathrm{r}=29 \%)$. The specimen with high-density precipitates of the $\mathrm{Ni}_{3} \mathrm{Nb}$ phase in the grain interior exhibited a much higher y. The value of y of $\mathrm{Fe}-20 \mathrm{Cr}-30 \mathrm{Ni}-2 \mathrm{Nb}$ steel can be controlled by changing the precipitation morphology in the grain interior. Fractographic observations demonstrate that ductile intragranular fracture occurred in all of the tested specimens. The absorption energy measured by the Charpy impact test decreased from 211 to $31 \mathrm{~J} / \mathrm{cm}^{2}$ as was increased from 0 to $89 \%$. The fracture mode appeared to vary from ductile transgranular fracture to cleavage transgranular fracture with increasing. There was no indication of crack propagation within the precipitates of the Laves phase covering the grain boundaries or along the interface between $-\mathrm{Fe}$ and the Laves phase. Therefore, the Laves phase that precipitated on the grain boundaries would not have a negative effect on the room-temperature ductility.
\end{abstract}




\section{Introduction}

Advanced ultra-super-critical (A-USC) thermal power plants that are operated at $973 \mathrm{~K}$ require the development of steam-boiler tube and pipe materials with a $10^{5}$-h creep-rupture strength of more than $100 \mathrm{MPa}$ at $973 \mathrm{~K}$ [1-3]. Wrought Ni-based alloys can meet the operating conditions of A-USC plants [3], but owing to their high costs, austenitic heat-resistant steels are being considered as alternatives. However, conventional austenitic heat-resistant steels strengthened by carbides (e.g., TP347 steel) are not strong enough [4,5] because of their microstructure instability when exposed to elevated temperatures. Takeyama et al. proposed a design concept for novel austenitic heat-resistant steels strengthened by thermodynamically stable intermetallic phases [6]. The phase equilibria between the $\mathrm{Fe}_{2} \mathrm{M}$ Laves phase (M: transition metal) and the $\gamma$-Fe phase in $\mathrm{Fe}-\mathrm{Ni}-\mathrm{M}$ ternary systems have been systematically studied $[7,8]$. Based on the results, we have developed a novel austenitic heat-resistant steel with a composition of $\mathrm{Fe}-20 \mathrm{Cr}-30 \mathrm{Ni}-2 \mathrm{Nb}$ (at.\%), which is strengthened by the topologically close-packed (TCP) $\mathrm{Fe}_{2} \mathrm{Nb}$ Laves phase on grain boundaries, together with the geometrically close-packed (GCP) $\mathrm{Ni}_{3} \mathrm{Nb}$ phase in the grain interior $[9,10]$. This steel exhibits much higher creep-rupture strength [10-14] and superior oxidation resistance [15], and it meets the requirements for A-USC power plants $\left(973 \mathrm{~K}, 100 \mathrm{MPa}, 10^{5}\right.$-h creep-rupture strength) [12-14]. This superior long-term creep-rupture strength is mainly due to the stable TCP $\mathrm{Fe}_{2} \mathrm{Nb}$ Laves phase precipitated on the grain boundaries. We have demonstrated that increasing the area fraction of the $\mathrm{Fe}_{2} \mathrm{Nb}$ Laves phase on the grain boundaries ( ) in $\mathrm{Fe}-20 \mathrm{Cr}-30 \mathrm{Ni}-2 \mathrm{Nb}$ steel to a value above $80 \%$ can substantially reduce the creep rate during the entire creep stage $[16,17]$. Therefore, sufficiently covering grain boundaries with precipitates of the Laves phase would play a significant role in strengthening under creep at elevated temperatures. This strengthening mechanism concept is referred to as "grain boundary precipitation strengthening" $[10,12,14]$ by the stable Laves phase.

From an engineering perspective, the superior creep-rupture strength of 
$\mathrm{Fe}-20 \mathrm{Cr}-30 \mathrm{Ni}-2 \mathrm{Nb}$ steel indicates that it has the potential for application in steam-turbine components (turbine casings, rotor forgings, blades) of A-USC power plants. One of the required properties of materials for these applications is high yield strength and adequate ductility [3]. It is therefore essential to investigate the tensile properties of $\mathrm{Fe}-20 \mathrm{Cr}-30 \mathrm{Ni}-2 \mathrm{Nb}$ steel.

The $\mathrm{Fe}_{2} \mathrm{M}$ Laves phases are often present in conventional heat-resistant steels and alloys, and it is believed that they have an unfavorable effect on the mechanical properties of the materials $[18,19]$. It is generally known that the Laves phase is notoriously brittle at ambient temperature, which is attributed to the difficulty in moving dislocations under an applied shear stress [19-22]. However, $\mathrm{Fe}-20 \mathrm{Cr}-30 \mathrm{Ni}-2 \mathrm{Nb}$ steel with $=89 \%$ (i.e., the precipitates of the Laves phase cover $89 \%$ of the grain boundary) exhibits a high creep ductility of approximately $70 \%$ at elevated temperatures $[12,16,17]$, which demonstrates that the $\mathrm{Fe}_{2} \mathrm{Nb}$ Laves phase on grain boundaries does not reduce the creep ductility. Furthermore, it was recently found that the $\mathrm{Fe}_{2} \mathrm{Nb}$ Laves phase that is in equilibrium with the $-\mathrm{Fe}$ phase exhibits plasticity at room temperature [23,24]. Thus, the Laves phase on grain boundaries may not negatively affect the ductility of $\mathrm{Fe}-20 \mathrm{Cr}-30 \mathrm{Ni}-2 \mathrm{Nb}$ steel at ambient temperature.

In the present study, we examined the mechanical properties of $\mathrm{Fe}-20 \mathrm{Cr}-30 \mathrm{Ni}-2 \mathrm{Nb}$ steel with controlled microstructures by conducting tensile tests and Charpy impact tests. The results were then utilized to investigate two issues: (1) whether the yield strength of $\mathrm{Fe}-20 \mathrm{Cr}-30 \mathrm{Ni}-2 \mathrm{Nb}$ is high enough to permit the alloy to be applied in steam-turbine components (turbine casings, rotor forgings, blades); (2) the effect of the $\mathrm{Fe}_{2} \mathrm{Nb}$ Laves phase at grain boundaries on the ductility of $\mathrm{Fe}-20 \mathrm{Cr}-30 \mathrm{Ni}-2 \mathrm{Nb}$ steel at room temperature.

\section{Experimental procedure}

The nominal composition (at.\%) of the steel specimens examined in our study was $\mathrm{Fe}-20 \mathrm{Cr}-30 \mathrm{Ni}-2 \mathrm{Nb}$ (base steel). Some specimens were doped with 0.03 at.\% of B (B-doped steel) to increase . Other specimens were doped with 0.1 at.\% of 
$\mathrm{Zr}$ (Zr-doped steel) to stabilize the precipitation morphology of the fine GCP

"- $\mathrm{Ni}_{3} \mathrm{Nb}$ phase in the grain interior. The chemical compositions of the studied steels measured by wet chemical analysis were shown in Table 1 . These steel specimens were prepared by vacuum induction melting and hot-forged into rods with a diameter of $12 \mathrm{~mm}$ at $1553 \mathrm{~K}$. Subsequently, they were solution-treated at $1473-1523 \mathrm{~K}$ for $2 \mathrm{~h}$ to control the grain size to about $150 \mathrm{~m}$. In order to change

from 0 to $89 \%$, the solution-treated steels were aged at 973 and $1073 \mathrm{~K}$. During aging at $973 \mathrm{~K}$, the $\mathrm{Fe}_{2} \mathrm{Nb}$ Laves phase precipitated on the grain boundaries and the $\mathrm{Ni}_{3} \mathrm{Nb}$ phase precipitated in the grain interior; during aging at $1073 \mathrm{~K}$, only the $\mathrm{Fe}_{2} \mathrm{Nb}$ Laves phase precipitated on the grain boundaries and in the grain interior. Figure 1 shows the time-temperature-precipitation (TTP) diagram of the base steel [10].

Tensile tests of standard specimens (JIS-G0567 II-6) with a gauge length of 28 $\mathrm{mm}$ was carried out at room temperature at a strain rate of $3.0 \times 10^{-4} / \mathrm{s}$ (corresponding to a cross-head speed of $8.4 \times 10^{-6} \mathrm{~m} / \mathrm{s}$ ) using a Shimazu Autograph AG-X. To evaluate the impact toughness, the load-displacement curves and the absorption energy of the JIS-Z2202 standard specimens $(55 \mathrm{~mm} \times 10 \mathrm{~mm}$ $\times 5 \mathrm{~mm}$ ) with a U-notch were measured at room temperature using the Charpy impact testing equipment (Yonekura MFG CHARPAC) at an input energy of $300 \mathrm{~J}$. The measured impact speed was approximately $5.0 \mathrm{~m} / \mathrm{s}$, which would give a strain rate of approximately $1.0 \times 10^{2} / \mathrm{s}$ in the Charpy impact test. Their microstructures and fracture surfaces were observed by scanning electron microscopy (SEM: JEOL JSM-7000F). The surface of the samples for observation of the microstructure was electropolished in a solution of $\mathrm{Cr}$-saturated phosphoric acid at $353 \mathrm{~K}, 20 \mathrm{~V}$, and 1 A for $2 \mathrm{~s}$. Thin discs for transmission electron microscopy (TEM) were cut from the aged steels, mechanically polished and twin-jet electro-polished in a solution of ethanol with 12 vol.\% perchloric acid at $253 \mathrm{~K}$. TEM observation was carried in a JEOL JEM-2010 microscope operated at $200 \mathrm{kV}$. The chemical compositions were analyzed using a JEOL JEM-2100F microscope equipped with an energy dispersive X-ray spectroscopy (EDS) system. 
(EDS). The hardness (HV) was measured using the Vickers indenter (Akashi MVK-H2) at a constant load of $9.8 \mathrm{~N}$ at room temperature.

The value of with respect to the total grain boundaries was quantitatively analyzed using Eq. (1), where $l$ and $L$ are the length of the grain boundary covered by Laves particles and the total length of the grain boundaries, respectively:

$$
\rho(\%)=\frac{l_{1}+l_{2}+l_{3}+l_{4}+\ldots}{L} \times 100
$$

The value of was measured from several backscattering electron images (BEIs) of the mechanically polished samples. The value of $L$ was approximately $1000 \mu \mathrm{m}$ in each sample.

\section{Results}

\subsection{Microstructure}

Figure 2 presents BEIs showing microstructures of the base and B-doped steels that were aged at $1073 \mathrm{~K}$. The solution-treated base steel exhibits an equiaxed microstructure of a single phase of $-\mathrm{Fe}$ with a mean grain size of $150 \mathrm{~m}$. Only the $\mathrm{Fe}_{2} \mathrm{Nb}$ Laves phase precipitated in the -Fe matrix at $1073 \mathrm{~K}$, as shown in Fig. 1. In the base steel that was aged for $240 \mathrm{~h}$, the granular precipitates of the Laves phase with a length of approximately $1 \mathrm{~m}$ preferentially precipitated on the grain boundaries in the -Fe matrix, and the plate-shaped precipitates of the Laves phase with a mean length below $1 \mathrm{~m}$ were dispersed rather homogenously in the grain interior (Fig. 2(a)). In the B-doped steel that was aged for $240 \mathrm{~h}$, a large part of the grain boundaries was covered by precipitates of the Laves phase $(=80 \%)$. The precipitates often connected each other, resulting a mean length of precipitates above $3 \mathrm{~m}$. The precipitation morphology of the Laves phase in the grain interior was coarser than that observed in the base steel (Fig. 2(b)). The length of the Laves phase in grain interior was approximately $2 \mathrm{~m}$, which was twice larger than that in the base steel. After $1200 \mathrm{~h}$, increased to $89 \%$ and the mean thickness of the Laves phase on grain boundaries became slightly larger to approximately $0.7 \mathrm{~m}$. The mean length of the Laves phase in grain interior 
became larger to approximately $3 \mathrm{~m}$, whereas the precipitation density in the grain interior decreased (Fig. 2(c)). The change in microstructure of the Zr-doped steel with aging is somewhat different from that of the base and B-doped steel. After 24 h (Fig. 2(d)), the fine plate-shaped precipitates were locally observed in grain interior, together with the Laves phase. The fine precipitates corresponds to the $\mathrm{Ni}_{3} \mathrm{Nb}$ phase. The precipitation morphology becomes coarse after $1200 \mathrm{~h}$.

Figure 3 presents a TEM image showing the precipitates in -Fe matrix of the base steel aged at $1073 \mathrm{~K}$ for $240 \mathrm{~h}$. The selected area electron diffraction pattern (SAED) pattern was obtained from the corresponding region of (b) in the TEM image (Fig. 3(a)). The SAED pattern (Fig. 3(b)) represents the incident beams parallel to [110] of $-\mathrm{Fe}$ (fcc structure) and [10-10] of $-\mathrm{Fe}_{2} \mathrm{Nb}$ Laves phase (hexagonal $\mathrm{C} 14$ structure), which identify the $\mathrm{Fe}_{2} \mathrm{Nb}$ Laves phase precipitated in the -Fe matrix. This pattern represents that a (0001) plane of the Laves phase is parallel to a (-111) plane of the -Fe matrix. The diffraction pattern is indicative of a particular orientation relationship of (0001) // (111) and [10-10] // [-110], as also reported in the literature [25]. Note that the $\mathrm{Fe}_{2} \mathrm{Nb}$ Laves phase precipitated on grain boundaries was identified using SAED patterns as well.

Figure 4 presents secondary electron images (SEIs) showing microstructures of the base and Zr-doped steels aged at $973 \mathrm{~K}$. In the base steel aged for $240 \mathrm{~h}$ (Fig. $4(\mathrm{a})$ ), a fine $"-\mathrm{Ni}_{3} \mathrm{Nb}$ phase (tetragonal $\mathrm{D}_{22}$ structure) with a mean size below 0.5 $\mathrm{m}$ precipitated in the grain interior, whereas the granular precipitates of the Laves phase with a mean length of approximately $0.5 \mathrm{~m}$ were present on the grain boundaries. After aging for $1200 \mathrm{~h}$ (Fig. 4(b)), rod-shaped precipitates of the $-\mathrm{Ni}_{3} \mathrm{Nb}$ phase (orthorhombic $\mathrm{D} 0_{\mathrm{a}}$ structure) with a mean length of approximately $2 \mathrm{~m}$ were often present and replaced the fine " phase, resulting in the coarser precipitation morphology in the grain interior. The phase determination by TEM was described in detail later. This indicates a transformation from the metastable " phase to the stable phase at $973 \mathrm{~K}$, as shown in Fig. 1. In the Zr-doped steel, numerous fine precipitates of the " phase with a mean size below $0.5 \mathrm{~m}$ were homogenously dispersed within the grains (Fig. 4(c)). The fine precipitation 
morphology remained unchanged even after $1200 \mathrm{~h}$ (Fig. 4(d)). There were very few rod-shaped precipitates of the phase in the grain interior. Note that the $\mathrm{Fe}_{2} \mathrm{Nb}$ Laves phase precipitated on the grain boundaries in the $\mathrm{Zr}$-doped steel as well as the base steel.

Figure 5 presents TEM images showing the precipitates in -Fe matrix of (a) the base steel and (b) the $\mathrm{Zr}$-doped steel aged at $973 \mathrm{~K}$ for $240 \mathrm{~h}$. The SAED patterns represents the incident beam parallel to [001]. The diffractions derived from the fine precipitates obviously indicate three variants of the "- $\mathrm{Ni}_{3} \mathrm{Nb}$ phase (tetragonal $\mathrm{D}_{22}$ structure) with the $-\mathrm{Fe}$ matrix (fcc structure) on the basis of an orientation relationship of $(001) " / /(100)$ and [100] "// [010] [26], which has been often observed in the wrought Ni-based alloys [27]. In the base steel, a number of dislocations were observed around the plate-shaped " phase with a mean length of $200 \mathrm{~nm}$, whereas in the Zr-doped steel, high strain contrast can be obviously observed within the -Fe matrix around the homogeneously dispersed " phase with a mean length of $100 \mathrm{~nm}$, indicating high coherency of the interface between the " phase and the -Fe matrix. Figure 6 shows (a) a TEM image of the fine $"-\mathrm{Ni}_{3} \mathrm{Nb}$ phase in the $-\mathrm{Fe}$ matrix and (b) corresponding the composition line profiles across the " phase in the Zr-doped steel aged at $973 \mathrm{~K}$ for $240 \mathrm{~h}$. The EDS line analysis revealed high concentration of $\mathrm{Nb}$ above $22 \%$ in the location of the "- $\mathrm{Ni}_{3} \mathrm{Nb}$ phase (Fig. 6(b)). It is noteworthy that a trace $\mathrm{Zr}$ element was detected within the " phase (Fig. 6(c)), indicating that the added $\mathrm{Zr}$ element is localized within the " phase rather than the -Fe matrix. The result suggests that the addition of trace $\mathrm{Zr}$ could stabilize the fine "- $\mathrm{Ni}_{3} \mathrm{Nb}$ phase, resulting in the stable precipitation morphology in the grain interior after long-term aging (Fig. 4(d)). The stabilization of the " phase by $\mathrm{Zr}$ might be associated with the precipitation of the $\mathrm{Ni}_{3} \mathrm{Nb}$ phase at $1073 \mathrm{~K}$ (Fig. 2(d)) as well as $973 \mathrm{~K}$.

A TEM image showing the precipitates in the base steel aged at $973 \mathrm{~K}$ for 3600 $\mathrm{h}$ is presented in Fig. 7. The selected area electron diffraction pattern (SAED) pattern was obtained from the corresponding region of (b) in the TEM image (Fig. 7(a)). The SAED pattern (Fig. 7(b)) represents the incident beams parallel to 
[-111] of -Fe with fcc structure and [010] of the $-\mathrm{Ni}_{3} \mathrm{Nb}$ phase with an orthorhombic $\mathrm{D}_{\mathrm{a}}$ structure, indicating the phase precipitated in the -Fe matrix. This pattern represents that a nominal direction of a [100] plane of the Laves phase is parallel to that of a (110) plane of the -Fe matrix, which suggests an orientation relationship of (010) // (111) and [100]// [1-10], as previously determined in the literature [28].

Figure 8 shows the changes in hardness measured in the grains and with aging time at $1073 \mathrm{~K}$ (only the $\mathrm{Fe}_{2} \mathrm{Nb}$ Laves phase precipitated during that time in the base steel, as shown in Fig. 1). The hardness of the solution-treated steels was approximately $1.4 \mathrm{GPa}$. In the base steel, the hardness increased with increasing aging time and reached $1.8 \mathrm{GPa}$ after $3600 \mathrm{~h}$, which was caused by precipitation of the Laves phase in the grain interior (Fig. 2(a)). The B-doped steel showed a trend similar to that of the base steel, and its maximum hardness was $1.7 \mathrm{GPa}$. In the Zr-doped steel, the hardness increased to $1.9 \mathrm{GPa}$ after $24 \mathrm{~h}$ (which is likely due to the fine precipitates of the $\mathrm{Ni}_{3} \mathrm{Nb}$ phase in grain interior (Fig. 2(d))), but slightly decreased to $1.8 \mathrm{GPa}$ after $1200 \mathrm{~h}$. The value of obviously changed depending on the type of steel used in the study (Fig. 8(b)). In the base steel, increased with increasing aging time and reached approximately 50\% after $3600 \mathrm{~h}$. In the B-doped steel, significantly increased with an increase in aging time and reached $89 \%$ after $1200 \mathrm{~h}$ (Fig. 2(c)), which is twice that of the base steel. The Zr-doped steel exhibited a relatively high and the maximum value was approximately $60 \%$.

Figure 9 shows the changes in hardness measured in the grains and with aging time at $973 \mathrm{~K}$. During this period, the $\mathrm{Fe}_{2} \mathrm{Nb}$ Laves phase precipitated on the grain boundaries and the $\mathrm{Ni}_{3} \mathrm{Nb}$ phase precipitated in the grain interior, as shown in Fig. 1). The Zr-doped steel showed significant age hardening when compared with the base steel and the B-doped steel (Fig. 9(a)). The hardness of the base steel and B-doped steel increased to $2.2 \mathrm{GPa}$ after $1200 \mathrm{~h}$ owing to the precipitation of the " and phases within the grains (Fig. 3(b)). The hardness of the Zr-doped steel significantly increased to $2.7 \mathrm{GPa}$ after $1200 \mathrm{~h}$, which was responsible for the 
fine precipitation morphology of the " phase in the grain interior (Fig. 4(d)). increased with increasing aging time at $973 \mathrm{~K}$ as well, whereas the steels aged at $973 \mathrm{~K}$ (Fig. 9(b)) exhibited lower than those aged at $1073 \mathrm{~K}$ (Fig. 8(b)). The B-doped steel exhibited the highest of more than $60 \%$ after $3600 \mathrm{~h}$, which is almost twice that of the base steel.

\subsection{Tensile test}

Figure 10 shows the true-stress-true-strain curves of specimens of the base steel and B-doped steel with different values of. The specimen of the solution-treated steel with $=0$ ( $210 \mathrm{MPa}$. The flow stress increased at an almost constant strain hardening rate and then reached a maximum of $900 \mathrm{MPa}$. The tensile elongation was $45 \%$. For the specimen with $=80 \%$ (the B-doped steel aged at $1073 \mathrm{~K}$ for $240 \mathrm{~h}$ ), yielding occurred at $238 \mathrm{MPa}$ and then the flow stress increased at a higher strain hardening rate to approximately $900 \mathrm{MPa}$. The maximum stress was almost the same as that of the specimen with $=0$. The tensile elongation was approximately $30 \%$, which is lower than that of the specimen with $=0$. A similar flow curve was obtained for the specimen with $=43 \%$ (the base steel aged at $1073 \mathrm{~K}$ for 240 h). Its tensile elongation was approximately $30 \%$, which is similar to that of the specimen with $=80 \%$.

Figure 11 shows the true-stress-true-strain curves of the specimens of base steel and Zr-doped steel aged at $973 \mathrm{~K}$. These specimens showed fine precipitates of the " phase in the grain interior and relatively low (Fig. 4(a, c)). For the specimen with $=33 \%$ (Fig. 4(a)), yielding occurred at $301 \mathrm{MPa}$, after which the flow stress increased to approximately $900 \mathrm{MPa}$. The maximum stress was almost the same as that of the specimen with $=0$. The specimen with $=22 \%$ (Fig. 4(c)) exhibited a higher yield strength of $490 \mathrm{MPa}$ owing to the high-density precipitates of the fine " phase in the grain interior, whereas it exhibited a maximum stress level of $980 \mathrm{MPa}$, which is similar to those of the other specimens. The specimen with $=22 \%$ exhibited the lowest tensile elongation of $21 \%$ among 
the tested specimens. These curves demonstrate that the yield strength could be increased by controlling the precipitation morphology in the grain interior, especially for the $\mathrm{Ni}_{3} \mathrm{Nb}$ - " phase in $\mathrm{Fe}-20 \mathrm{Cr}-30 \mathrm{Ni}-2 \mathrm{Nb}$ steel. The mechanical properties measured by the tensile test are summarized in Table 2. Note that the solution-treated B-doped and Zr-doped steels exhibit similar tensile properties to the solution-treated base steel. This suggests that the solute B and $\mathrm{Zr}$ elements in the studied steels have a negligible effect on the tensile properties at ambient temperature.

The macroscopic fractographs and representative images of fracture surfaces of the tensile-tested specimens with different values are shown in Figs. 12 and 13. The specimen with $=0$ (solution-treated steel) showed a necking (Fig. 12(a)), and numerous spherical dimples were found on the entire fracture surface (Fig. 12(b)), which is indicative of ductile fracture. A similar dimple pattern was observed on the fracture surface of the specimen with $=80 \%$ (Fig. 12(c, d)). The fracture surface of the tested specimen with $=43 \%$ also showed a fine dimple pattern (Fig. 12(e, f)). It should be noted that precipitates of the Laves phase were not observed on the fracture surfaces of all specimens. In the specimen of base steel aged at $973 \mathrm{~K}$ with $=31 \%$, the dimple pattern was clearly observed (Fig. 13(a,b)). Fine spherical dimples were also observed on the fracture surface of the specimen of Zr-doped steel that was aged at $973 \mathrm{~K}$ with $=22 \%$ (Fig. 13(c, d)). Distinctive flat surfaces (which would be indicative of a brittle nature) were not found on the fracture surface of any of the specimens. These topographical features of the fracture surfaces demonstrate ductile intragranular fracture in all of the tested specimens. These ductile fracture surfaces were observed in the $\mathrm{Fe}-20 \mathrm{Cr}-30 \mathrm{Ni}-2 \mathrm{Nb}-5 \mathrm{Al}$ steel strengthened by the $\mathrm{Fe}_{2} \mathrm{Nb}$ Laves phase and $\mathrm{NiAl}$ phase (B2 structure) as well [29].

Figure 14 shows the changes in tensile elongation as functions of and $\mathrm{HV}$ measured in the grains. HV indicates the difference in hardness (measured by the Vickers indentation test) between the solution-treated sample (about $1.25 \mathrm{GPa}$ ) and aged samples, which is closely associated with the interparticle spacing, 
particle size and volume fraction of precipitates in the grain interior. The tensile elongations with the specimens with $>0$ were lower than that of the specimen with $=0$, whereas a clear correlation between the tensile elongation and was not found (Fig. 14(a)). The tensile elongation remained high at about 30\%, even when was as high as $80 \%$. On the other hand, the tensile elongation continuously decreased with increasing HV (Fig. 14(b)). In particular, the specimen with the highest $\mathrm{HV}$ of $1.1 \mathrm{GPa}$ (Zr-doped steel aged at $973 \mathrm{~K}$ for $240 \mathrm{~h}$, (Fig. 4(c)) exhibited the lowest tensile elongation and a low of $22 \%$. These results obviously indicates that the reduced tensile ductility would be responsible for the fine precipitates (Laves phase or " phase) in the grain interior rather than the Laves phase covering on grain boundaries.

\subsection{Charpy impact test}

Figure 15 shows the load-displacement curves of the specimens with $=80 \%$ (B-doped steel aged at $1073 \mathrm{~K}$ for $240 \mathrm{~h}$, Fig. 2(b)) and $=89 \%$ (B-doped steel aged at $1073 \mathrm{~K}$ for $1200 \mathrm{~h}$, Fig. 2(c)) during the Charpy impact test, together with the result of the specimen with $=0$ (solution-treated steel). For the specimen with $=0$, the load was linearly increased with an increase in the displacement before yielding at a load of approximately $4.5 \mathrm{kN}$. The load was increased to $7 \mathrm{kN}$ at a displacement of approximately $12 \mathrm{~mm}$ and then decreased to zero at $27 \mathrm{~mm}$. Its absorption energy was $211 \mathrm{~J} / \mathrm{cm}^{2}$. For the specimen with $=80 \%$, yielding occurred at a load of approximately $5 \mathrm{kN}$ and then the load was increased to the maximum of $7.5 \mathrm{kN}$ at a displacement of $3 \mathrm{~mm}$, followed by a load drop, which resulted in an absorption energy of $53 \mathrm{~J} / \mathrm{cm}^{2}$. The specimen with $=89 \%$ exhibited the same yielding at a load of $5 \mathrm{kN}$ as the specimen with $=80 \%$, whereas it was subjected to a lower maximum load of approximately $6 \mathrm{kN}$. Its absorption energy was $31 \mathrm{~J} / \mathrm{cm}^{2}$. The absorption energies measured by the Charpy impact test are summarized in Table 1.

Figure 16 shows fracture surfaces of the impact-tested specimens with various values of. The specimen with $=0$ exhibited a typical dimple pattern on the 
entire fracture surface (Fig. 16(a, b)), which is an indication of ductile fracture. For the specimen with $=80 \%$, numerous dimples were observed on the major part of the fracture surface (Fig. 16(d)), whereas flat fracture planes were observed locally (Fig. 16(c)). The flat planes were observed more often in the tested specimen with $=89 \%$ (Fig. 16(e)), together with the dimple pattern on the major part of the fracture surface (Fig. 16(f)). The flat planes might correspond to the cleavage fracture planes within the -Fe grains. Figure 17 shows BEIs (cross-sectional views) of the fractured portions of the tested specimens with $=0$, $80 \%$, and $89 \%$, which reveal that the major route of the crack propagation was through the grain interior in all specimens. These results demonstrate that transgranular fracture occurred during the impact deformation, although the fracture mode appeared to vary from the ductile fracture to the cleavage fracture with increasing .

Figure 18 shows the load-displacement curve of the specimen with $=36 \%$ (Zr-doped steel aged at $973 \mathrm{~K}$ for $1200 \mathrm{~h}$ ), which had a high density of fine " phase in the grain interior (Fig. 5(d)), together with a curve of the specimen with $=0$ (solution-treated steel). The flow curve of the specimen with $=36 \%$ shows that yielding occurred at a load of approximately $7.5 \mathrm{kN}$, and the specimen was subjected to a maximum load of approximately $9.5 \mathrm{kN}$ at a displacement of $4 \mathrm{~mm}$. The absorption energy was $106 \mathrm{~J} / \mathrm{cm}^{2}$, which is much lower than the value (211 $\mathrm{J} / \mathrm{cm}^{2}$ ) of the specimen with $=0 \%$. The fracture surface of the impact-tested specimen with $=36 \%$ is shown in Fig. 19. There were considerable flat fracture planes (Fig. 19(a)) on this specimen as well as the specimens with $=80$ and $89 \%$ (Fig. 16(c, e)), and numerous fine dimples were also observed on the fracture surface of the specimen with $=36 \%$ (Fig. 19(b)). The fractographic features were observed in the other type of austenitic heat-resistant steel [30]. These results indicate that transgranular fracture occurred in the specimen with $=36 \%$, as well as the specimen with $>80 \%$.

The absorption energies measured by the Charpy impact test are plotted in Fig. 20 as functions of and HV. As shown in Fig. 20(a), the absorption energy 
decreased with an increase in . On the other hand, the absorption energy dropped to $31 \mathrm{~kJ} / \mathrm{cm}^{2}$ at a $\mathrm{HV}$ value of $0.35 \mathrm{GPa}$, whereas it became constant at approximately $90 \mathrm{~kJ} / \mathrm{cm}^{2}$ for $\mathrm{HV}>0.7 \mathrm{GPa}$ (Fig. 20(b)). These results indicate that both the covering of grain boundaries by the Laves phase (an increase in ) and the higher density of fine precipitates in the grain interior (higher HV) contributed to the reduced impact ductility.

\section{Discussion}

In the present study, the mechanical properties of $\mathrm{Fe}-20 \mathrm{Cr}-30 \mathrm{Ni}-2 \mathrm{Nb}$ steels with different area fractions of the $\mathrm{Fe}_{2} \mathrm{Nb}$ Laves phase on grain boundaries (indicated by ) and different precipitation densities in the grain interior (indicated by HV) were examined by tensile tests and Charpy impact tests at ambient temperature. The tensile tests demonstrated that the yield stress increased from 210 to $490 \mathrm{MPa}$ owing to high-density precipitates of the fine "phase in the grain interior, which indicates that the yield strength of the steels could be effectively controlled by controlling the precipitation morphology of the GCP $\mathrm{Ni}_{3} \mathrm{Nb}$ phase in the grain interior. Trotter and Baker [29] show the yield strength controlled by the interparticle spacing in the grain interior in the $\mathrm{Fe}-20 \mathrm{Cr}-30 \mathrm{Ni}-2 \mathrm{Nb}-5 \mathrm{Al}$ steel. In the $\mathrm{Fe}-20 \mathrm{Cr}-30 \mathrm{Ni}-2 \mathrm{Nb}$ steel, the $\mathrm{Zr}$ addition is one of effective approaches to control the interparticle spacing of the " phase. The controllable yield strength is favorable for application of the present steel in materials for turbine casings and rotor forgings in the steam turbine of A-USC power plants. In addition, the aged specimens exhibited Charpy absorption energies ranging from 31 to $106 \mathrm{~J} / \mathrm{cm}^{2}$ at ambient temperature, which presents an adequate ductility compared with conventional austenitic heat-resistant alloys (e.g., alloy 617 [31], alloy 740 [32]) as candidate steam-boiler tube and pipe materials for A-USC power plants.

The present results can also be utilized to discuss the effect of $\mathrm{Fe}_{2} \mathrm{Nb}$ Laves phase precipitated on grain boundaries on the ductility at ambient temperature. In tensile deformation (at a lower strain rate of $3.0 \times 10^{-4} / \mathrm{s}$ ), the elongation decreased with increasing (Figs. 10 and 14 (a)), whereas the fractographs of the 
tested specimens showed that transgranular fracture occurred in all specimens, even the one with high (Fig. 12). This indicates that the precipitates of the Laves phase on grain boundaries would not cause fracture in tensile deformation. An important finding in the quest to understand the reduced tensile ductility was that the specimen with $=80 \%$ exhibited a higher strain hardening rate than the specimen with $=0$, whereas both specimens had the same maximum stress level of approximately $900 \mathrm{MPa}$ (Fig. 10). The stress-strain curves of the specimens with $=0$ and $80 \%$ are schematically shown in Fig. 21. The strain hardening was caused by the Laves phase precipitates in the grain interior rather than the grain-boundary Laves phase, which led to a larger slope of the flow curve for the specimen with $=80 \%$. The flow stress reached the maximum strength at a lower strain, which resulted in the decreasing tensile elongation with increasing . The maximum stress level corresponded to the intragranular strength of the -Fe matrix. The intragranular strength might be lower than the intergranular strength or the interface strength between $-\mathrm{Fe}$ and the Laves phase, which supported by no intergranular fracture observed in all specimens. Furthermore, the other specimens with different values exhibited similar maximum strength levels (Figs. 10 and 11) as well as transgranular fracture modes (Figs. 12 and 13). These results can be understood on the basis of the enhanced strain hardening by the Laves phase precipitates or fine " phase in the grain interior that caused the reduction of the tensile ductility of $\mathrm{Fe}-20 \mathrm{Cr}-30 \mathrm{Ni}-2 \mathrm{Nb}$ steels.

Figure 18 shows a plot of the absorption energies of specimens with different values versus the deformation rate. The absorption energies at a deformation rate of $8.6 \times 10^{-6} \mathrm{~m} / \mathrm{s}$ were measured using the stress-strain curves obtained by the tensile test. The absorption energies of all specimens became lower at a higher deformation rate, whereas a higher absorption energy at lower was observed at different deformation rates. This result indicates a trend of the room-temperature ductility associated with regardless of strain rate. Our fractographical investigations for the impact-tested specimens demonstrated that transgranular fracture occurred, even in the specimen with $=89 \%$ (Figs. 16 and 17). There was 
no indication of crack propagation within the Laves phase precipitates covering the grain boundaries or along the interface between -Fe and the Laves phase. Therefore, the $\mathrm{Fe}_{2} \mathrm{Nb}$ Laves phase that precipitated on the grain boundaries would not negatively affect the room-temperature ductility. However, the effect would be valid in case of the Laves phase with a controlled thickness less than $2 \mathrm{~m}$ (within an approximate thickness range from $0.5 \mathrm{~m}$ to $2 \mathrm{~m}$ examined in the present study). The coarse precipitates of the Laves phase with several micrometers are often observed in the heat-resistant steels and alloys [18]. Such coarse Laves phase could lead to the stress concentration for the initiations of crack to fracture the materials resulting in the reduced ductility. Thus, it is required to control the morphology of the Laves phase precipitated on grain boundaries for strengthening without a loss of the ductility.

The fractographic observations revealed that local flat fracture planes were present on the fracture surface of the impact-tested specimens with reduced absorption energy (Figs. 16 and 19). This suggests that the cleavage transgranular fracture occurred locally and would be associated with the reduction in impact ductility. This distinctive fracture plane was observed not only in the specimen with $=80$ and $89 \%$ (Fig. 2(c, d)), but also in the specimen with $=36 \%$ (Fig. 3(d)). Therefore, the precipitates of the Laves phase or fine " phase in the grain interior might have been related to the occurrence of cleavage-type fracture within the -Fe grains, which caused the reduction in the impact ductility.

\section{Summary}

We examined the mechanical properties of austenitic heat-resistant $\mathrm{Fe}-20 \mathrm{Cr}-30 \mathrm{Ni}-2 \mathrm{Nb}$ (at.\%) steels with controlled microstructures by conducting tensile tests and Charpy impact tests at room temperature. The key results are summarized as follows:

(1) The solution-treated specimen $(=0)$ exhibited a yield strength of $210 \mathrm{MPa}$ and a tensile elongation of $45 \%$. The yield stress was increased to $490 \mathrm{MPa}$ by 
high-density precipitates of the fine " phase in the grain interior, indicating that the yield strength of $\mathrm{Fe}-20 \mathrm{Cr}-30 \mathrm{Ni}-2 \mathrm{Nb}$ steels could be effectively controlled by controlling the precipitation morphology of the GCP $\mathrm{Ni}_{3} \mathrm{Nb}$ phase in the grain interior.

(2) The specimen with $=80 \%$ exhibited a lower tensile elongation (23\%) than the specimen with $=0$, whereas ductile transgranular fracture occurred regardless of the value of . The decrease in tensile ductility with increasing was responsible for the strain hardening in the $-\mathrm{Fe}$ matrix by fine precipitates in the grain interior.

(3) The solution-treated specimen with $=0$ exhibited an absorption energy of $211 \mathrm{~J} / \mathrm{cm}^{2}$ in the Charpy impact test. The absorption energy decreased to $31 \mathrm{~J} / \mathrm{cm}^{2}$ as increased to $89 \%$. The fracture mode appeared to vary from the ductile transgranular fracture to cleavage transgranular fracture with increasing, which was likely associated with the precipitation density in the grain interior. There was no indication of crack propagation within precipitates of the Laves phase covering the grain boundaries or along the interface between -Fe and the Laves phase. Thus, the Laves phase that precipitated on grain boundaries would not have a negative effect on the impact ductility.

\section{Acknowledgments}

This research was conducted under the Advanced Low Carbon Technology Research and Development Program (ALCA), Japan Science and Technology Agency (JST). The financial support from the program (JY220215) is highly acknowledged.

\section{References}

[1] R. Viswanathan, J.F. Henry, J. Tanzosh, G. Stanko, J. Shingledecker, B. Vitalis, R. Purgert, U.S. Program on Materials Technology for Ultra-Supercritical Coal Power Plants, JMEPEG 14 (2005), 281-292. 
[2] M. Fukuda, H. Semba, J. Iwasaki, S. Izumi, S. Takano, T. Takahashi, Y. Sumiyoshi, Advanced USC Technology Development in Japan, Advances in Materials Technology for Fossil Power Plants, Proceedings from the Seventh International Conference, October 22-25, 2013, Waikoloa, Hawaii, USA (2014), pp. 24-40.

[3] J. Shingledecker, R. Purgert, P. Rawls, Current Status of the U.S. DOE/OCDO A-USC Materials Technology Research and Development Program, Advances in Materials Technology for Fossil Power Plants, Proceedings from the Seventh International Conference, October 22-25, 2013, Waikoloa, Hawaii, USA (2014), pp. 41-52.

[4] K. Yoshikawa, H. Teranishi, K. Tokimasa, H. Fujikawa, M. Miura and K. Kubota, Fabrication and Properties of Corrosion Resistant TP347H Stainless Steel, J. Mater. Eng. 10 (1988), 69-84.

[5] H. Tanaka, S. Murata, K. Uehira, M. Yamasaki, K. Kimura, H. Abe, Precipitation Behavior during Long-Term Creep for SUS347 Stainless Steel, Report of the 123rd Committee on Heat-Resisting Materials and Alloys, Japan Society for the Promotion of Science (in Japanese), 47 (2006), 31-42.

[6] M. Takeyama, N. Gomi, S. Morita, T. Matsuo, Phase Equilibria and Lattice Parameters of $\mathrm{Fe}_{2} \mathrm{Nb}$ Laves Phase in Fe-Ni-Nb Ternary System at Elevated Temperatures Mater. Res. Soc. Symp. Proc. 842 (2005), 461-466.

[7] Y. Hasebe, K. Hashimoto, M. Takeyama, "Phase Equilibria among -Fe $/ \mathrm{Fe}_{2} \mathrm{Nb}$ (TCP) $/ \mathrm{Ni}_{3} \mathrm{Nb}(\mathrm{GCP})$ Phases in Fe-Ni-Nb Ternary System at Elevated Temperatures, J. Japan Inst. Metals (in Japanese), 75 (2011), 265-273.

[8] Y. Hasebe, K. Hashimoto, T. Matsuo, M. Takeyama, Assessment of the Phase Equilibria among $\gamma-\mathrm{Fe} / \mathrm{Fe}_{2} \mathrm{Nb} / \mathrm{Ni}_{3} \mathrm{Nb}$ Phases in Fe-Ni-Nb Ternary System at Elevated Temperatures, Mater. Res. Soc. Symp. Proc, 1295 (2011), 171-176.

[9] M. Takeyama, NOVEL CONCEPT OF AUSTENITIC HEAT RESISTANT STEELS STRENGTHENED BY INTERMETALLICS, Materials Science Forum, 539-543 (2007), 3012-3017.

[10] M. Takeyama, Fundamentals of Physical Metallurgy for High-temperature Materials - Microstructure Control and Design, NMS-ISIJ (in Japanese) 194-195 (2008) 3-23.

[11]K. Kurata, N. Takata, T. Matsuo, M. Takeyama, Effect of Grain Boundary $\mathrm{Fe}_{2} \mathrm{Nb}$ Laves Phase on Creep Resistance of Fe-20Cr-30Ni-2Nb Austenitic Heat Resistant Steel, Report of the $123^{\text {rd }}$ Committee on Heat-Resisting Materials and Alloys, Japan Society for the Promotion of Science (in Japanese), 49 (2008), 379-389.

[12] I. Tarigan, K. Kurata, N. Takata, T. Matsuo, M. Takeyama, Novel Concept of 
Creep Strengthening Mechanism using Grain Boundary $\mathrm{Fe}_{2} \mathrm{Nb}$ Laves Phase in Austenitic Heat Resistant Steel, Mater. Res. Symp. Proc., 1295 (2011), 317-322.

[13] I. Tarigan, N. Takata, M. Takeyama, Grain Boundary Precipitation Strengthening Mechanism by $\mathrm{Fe}_{2} \mathrm{Nb}$ Laves Phase in Creep of Fe-20Cr-30Ni-2Nb Austenitic Heat Resistant Steel, Proceedings of the $12^{\text {th }}$ International Conference on Creep and Fracture of Engineering Materials and Structure, May 27-31, 2012, Kyoto, Japan.

[14] M. Takeyama, I. Tarigan, N. Takata, M. Ueda, CREEP OF THE NOVEL AUSTENITIC HEAT RESISTANT STEELS STRENGTHEND BY $\mathrm{Fe}_{2} \mathrm{Nb}$ LAVES PHASE, Proceedings of the $3^{\text {rd }}$ International ECCC Conference, May 5-7, 2014, Rome, Italy.

[15] Lyta, M. Ueda, K. Kawamura, M. Takeyama, T. Maruyama, Microstructure Development of Oxide Scale during Steam Oxidation of the Fe-20Cr-30Ni-2Nb (at\%) Austenitic Steel at 1073 K, Mater. Trans., 54 (2013) $2276-2281$.

[16] Y. Misosaku, I. Tarigan, N. Takata, M. Ueda, T. Maruyama, M. Takeyama, Creep of the Novel Austenitic Heat Resistant Steel of Fe-20Cr-30Ni-2Nb under Steam Atmosphere at $1073 \mathrm{~K}$, Advances in Materials Technology for Fossil Power Plants, Proceedings from the Seventh International Conference, October 22-25, 2013, Waikoloa, Hawaii, USA, 2014, pp. 1352-1362.

[17] Y. Misosaku, I. Tarigan, T. Kimura, N. Takata, M. Ueda, T. Maruyama, M. Takeyama, Effect of Grain Boundary $\mathrm{Fe}_{2} \mathrm{Nb}$ Laves Phase on Creep of Austenitic Heat Resistant Steel of Fe-20Cr-30Ni-2Nb in Steam Atmosphere, Tetsu-to-Hagane (in Japanese) 100 (2014) 1158-1164.

[18] M.P. Sello, W.E. Stumpf, Laves phase embrittlement of the ferritic stainless steel type AISI 441, Mater. Sci. Eng. A 527 (2010) 5194-5202.

[19] D. I. Thoma, Intermetallics: Laves phase, in: K.H.J. Buschow, R.W. Cahn, M.C. Flemmings, B. Ilschner, E.J. Kramer, S. Mahajan (Eds.), Encyclopedia of Materials, Elsevier, Amsterdam, (2001) pp. 4205-4213..

[20] J.D. Livingston, Laves-phase superalloys?, Phys. Status Solidi A 13 (1992) 415-423.

[21] C.T. Liu, J.H. Zhu, M.P. Brady, C.G. McKamey, L.M. Pike, Physical metallurgy and mechanical properties of transition-metal Laves phase alloys, Intermetallics 8 (2000) 1119-1129.

[22] K.C. Chen, F. Chu, P.G. Kotula1, D. Thoma, HfCo2 Laves phase intermetallics-part II: elastic and mechanical properties as a function of composition, Intermetallics 9 (2001) 785-798. 
[23] N. Takata, H.G. Armaki, Y. Terada, M. Takeyama, K.S. Kumar, Plastic Deformation of the C14 Laves Phase (Fe,Ni) ${ }_{2} \mathrm{Nb}$, Scripta Mater. 63 (2013) 615-618.

[24] N. Takata, H.G. Armaki, M. Takeyama, S. Kumar, Nanoindentaiton Study on Solid Solution Softening of Fe-rich $\mathrm{Fe}_{2} \mathrm{Nb}$ Laves Phase by $\mathrm{Ni}$ in solution in Fe-Nb-Ni Ternary Alloys, Intermetallics 70 (2016) 7-16.

[25] G. Trotter, I. Baker, Orientation relationships of Laves phase and NiAl particles in an AFA stainless steel, Phil. Mag. 95 (2015) 4078-4094.

[26] J. He, S. Fukuyama, K. Yokogawa, "Precipitate in Inconel 718, J. Mater. Sci. Technol. 10(1994) 293-303.

[27] A. Niang, B. Viguier, J. Lacaze, Some features of an isothermal solid-state transformations in alloy 718, Mater. Char. 61(2010) 525-534.

[28] M. Sundararaman, P. Mukhopadhyay, S. Banerjee, Precipitation of the $-\mathrm{Ni}_{3} \mathrm{Nb}$ Phase in Two Nickel Base Superalloys, Metal. Trans. A 19(1988) 453-465.

[29] G. Trotter, I. Baker, The effect of aging on the microstructure and mechanical behavior of the alumina-forming austenitic stainless steel Fe-20Cr-30Ni-2Nb-5Al, Mater. Sci. Eng. A 627 (2015) 270-276.

[30] Bicao Peng, Hongxiang Zhang, Jie Hong, Jiaqiang Gao, Qijiang Wang, Hanqian Zhang, Effect of aging on the impact toughness of $25 \mathrm{Cr}-20 \mathrm{Ni}-\mathrm{Nb}-\mathrm{N}$ steel, Mater. Sci. Eng. A 527 (2010) 1957-1961.

[31] Y. Guo, B. Wang, S. Hou, Aging Precipitation Behavior and Mechanical Properties of Inconel 617 Superalloy, Acta. Metall. Sin. 26 (2013) 307-312.

[32] B. A. Baker, Advances in Materials Technology for Fossil Power Plants, Proc. the $6^{\text {th }}$ International Conference, Santa Fe, New Mexico, USA, (2010), pp. 96-109. 
Table 1 Chemical compositions of the studied steels measured by wet chemical analysis.

\begin{tabular}{c|cccccc}
\hline & \multicolumn{5}{|c}{ composition s/at. \% (wt.\%) } \\
\cline { 2 - 7 } & $\mathrm{Fe}$ & $\mathrm{Cr}$ & $\mathrm{Ni}$ & $\mathrm{Nb}$ & $\mathrm{B}$ & $\mathrm{Zr}$ \\
\hline \multirow{2}{*}{ Base } & \multirow{2}{*}{ Bal. } & 19.7 & 29.9 & 1.88 & - & - \\
& & $(18.1)$ & $(31.0)$ & $(3.1)$ & & \\
B-doped & Bal. & 19.8 & 29.9 & 2.01 & 0.03 & - \\
& & $(18.1)$ & $(31.0)$ & $(3.3)$ & $(0.006)$ & \\
& & 20.0 & 30.0 & 1.82 & & 0.07 \\
Zr-doped & Bal. & $(18.4)$ & $(31.1)$ & $(3.0)$ & - & $(0.12)$ \\
\hline
\end{tabular}


Table 2 Area fraction of the Laves phase on grain boundaries ( ), hardness (HV), and mechanical properties measured by tensile tests and Charpy impact tests.

\begin{tabular}{cccccccc}
\hline \multirow{2}{*}{ steel } & $\begin{array}{c}\text { aging } \\
\text { Condition }\end{array}$ & \multicolumn{2}{c}{ microstructure } & & tensile test & & $\begin{array}{c}\text { Charpy } \\
\text { impact test }\end{array}$ \\
\cline { 3 - 8 } & & $\rho / \%$ & $\mathrm{Hv} / \mathrm{GPa}$ & $\sigma_{\mathrm{y}} / \mathrm{MPa}$ & $\sigma_{\mathrm{U}} / \mathrm{MPa}$ & $\varepsilon / \%$ & $\begin{array}{c}\text { Absorption } \\
\text { energy } / \mathrm{Jcm}^{-2}\end{array}$ \\
\hline \multirow{5}{*}{ Base } & $1073 \mathrm{~K} / 240 \mathrm{~h}$ & 43 & 1.89 & 276 & 900 & 29 & 84 \\
& $1073 \mathrm{~K} / 1200 \mathrm{~h}$ & 52 & 1.91 & - & - & - & 71 \\
& $973 \mathrm{~K} / 240 \mathrm{~h}$ & 31 & 2.12 & 301 & 914 & 33.1 & - \\
& $973 \mathrm{~K} / 3600 \mathrm{~h}$ & 42 & 2.01 & - & - & - & 88 \\
\hline \multirow{3}{*}{ B-doped } & As solution treated & 0 & 1.30 & 214 & 869 & 45.1 & \\
& $1073 \mathrm{~K} / 24 \mathrm{~h}$ & 70 & 1.51 & 245 & 870 & 41.1 & - \\
& $1073 \mathrm{~K} / 240 \mathrm{~h}$ & 80 & 1.72 & 276 & 900 & 22.9 & 53 \\
& $1073 \mathrm{~K} / 1200 \mathrm{~h}$ & 89 & 1.61 & - & - & - & 31 \\
\hline \multirow{2}{*}{ Zr-doped } & As solution treated & 0 & 1.36 & 199 & 820 & 46.4 & - \\
& $973 \mathrm{~K} / 240 \mathrm{~h}$ & 22 & 2.34 & 490 & 984 & 21.5 & - \\
& $973 \mathrm{~K} / 1200 \mathrm{~h}$ & 36 & 2.69 & - & - & - & 106 \\
& $973 \mathrm{~K} / 3600 \mathrm{~h}$ & 48 & 2.47 & - & - & - & 87 \\
\hline
\end{tabular}




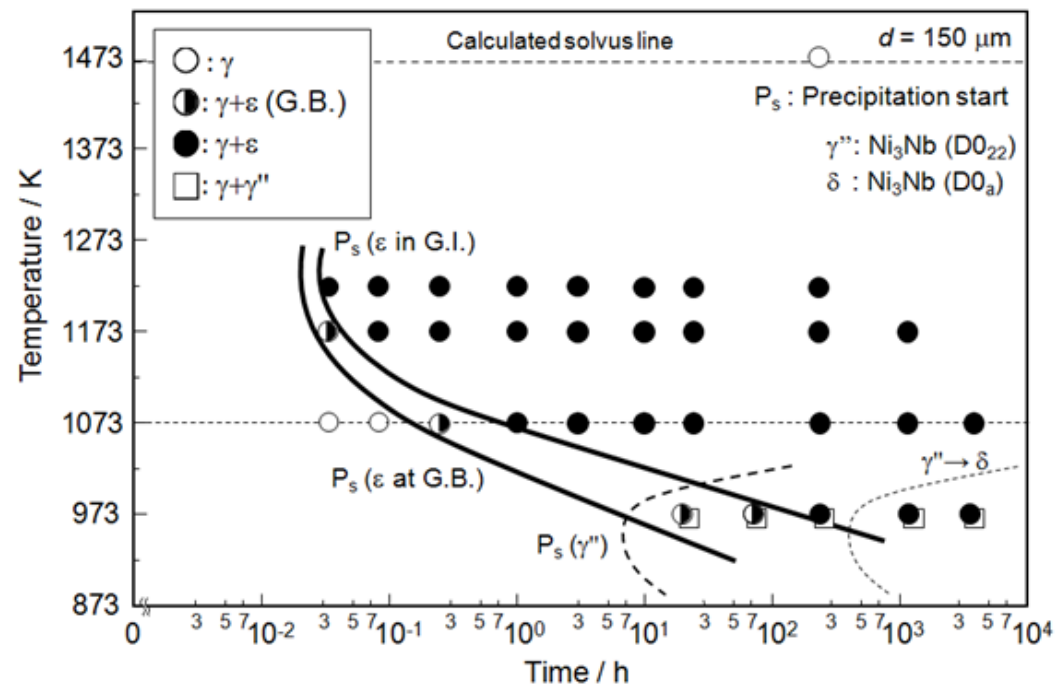

Fig. 1. Time-temperature-precipitation (TTP) diagram of $\mathrm{Fe}-20 \mathrm{Cr}-30 \mathrm{Ni}-2 \mathrm{Nb}$ steel alloy [10]. $\left(\mathrm{P}_{\mathrm{s}}\right.$ : start of precipitation; : $\mathrm{Fe}_{2} \mathrm{Nb}$-Laves phase $(\mathrm{C} 14) ; \gamma^{\prime \prime}: \mathrm{Ni}_{3} \mathrm{Nb}\left(\mathrm{D} 0_{22}\right) ; \delta: \mathrm{Ni}_{3} \mathrm{Nb}$ $\left(\mathrm{D} 0_{\mathrm{a}}\right)$; GB: grain boundary; GI: grain interior). 


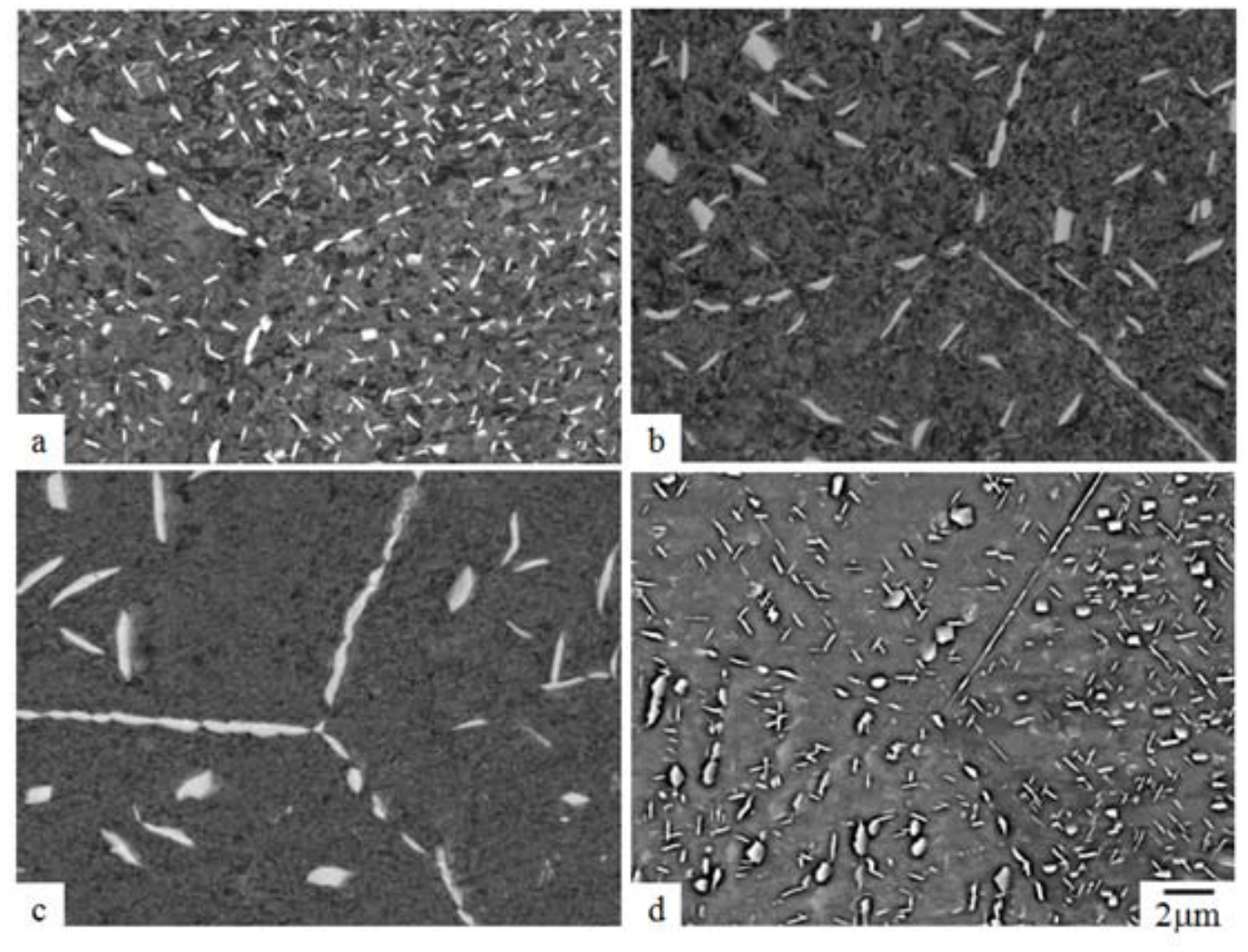

Fig. 2. Backscattered electron images (BEIs) showing microstructures of base steel and B-doped steel that were aged at $1073 \mathrm{~K}$ : (a) base steel, aged for $240 \mathrm{~h}$, (b) B-doped steel, aged for $240 \mathrm{~h}$, (c) B-doped steel, aged for $1200 \mathrm{~h}$, (d) Zr-doped steel, aged for $24 \mathrm{~h}$. 


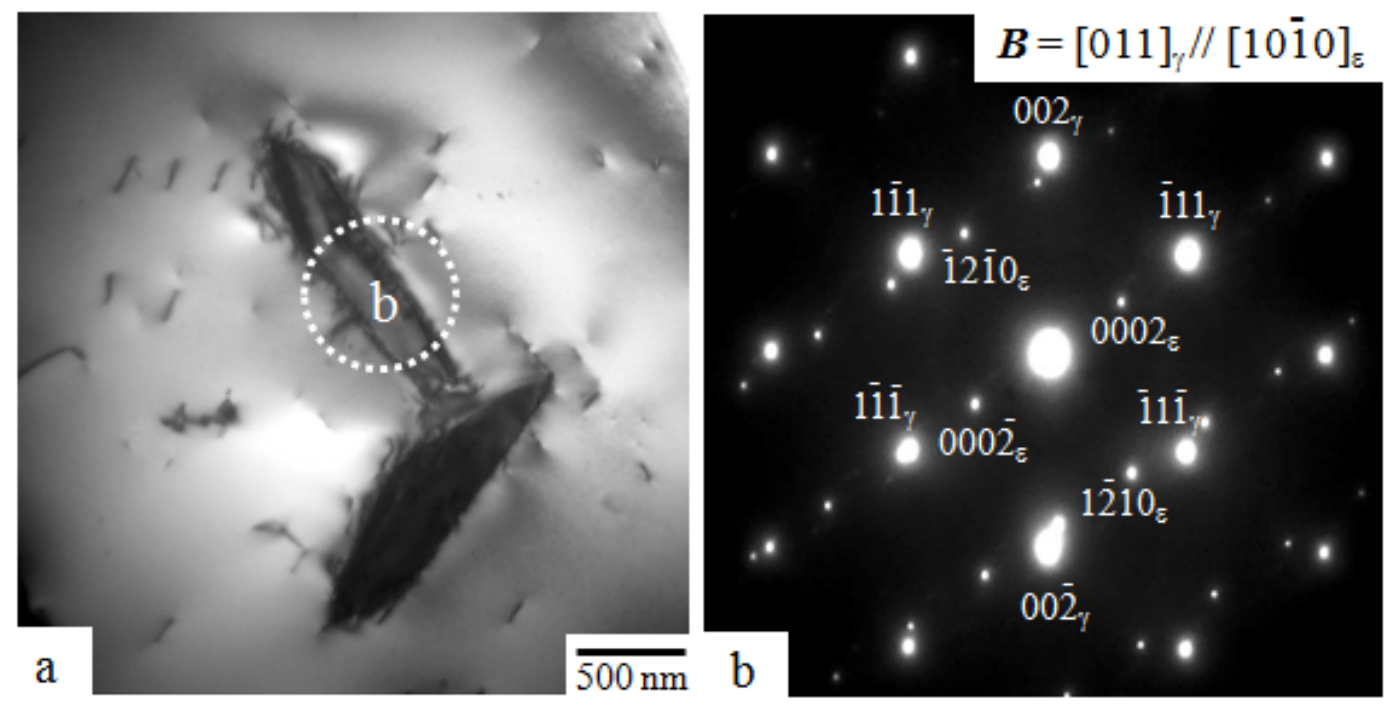

Fig. 3. (a) TEM bright field image showing the precipitates of $-\mathrm{Fe}_{2} \mathrm{Nb}$ Laves phase in $-\mathrm{Fe}$ matrix of the base steel aged at $1073 \mathrm{~K}$ for $240 \mathrm{~h}$ and (b) selected area electron diffractions obtained from the corresponding regions of (b) in the TEM image. 

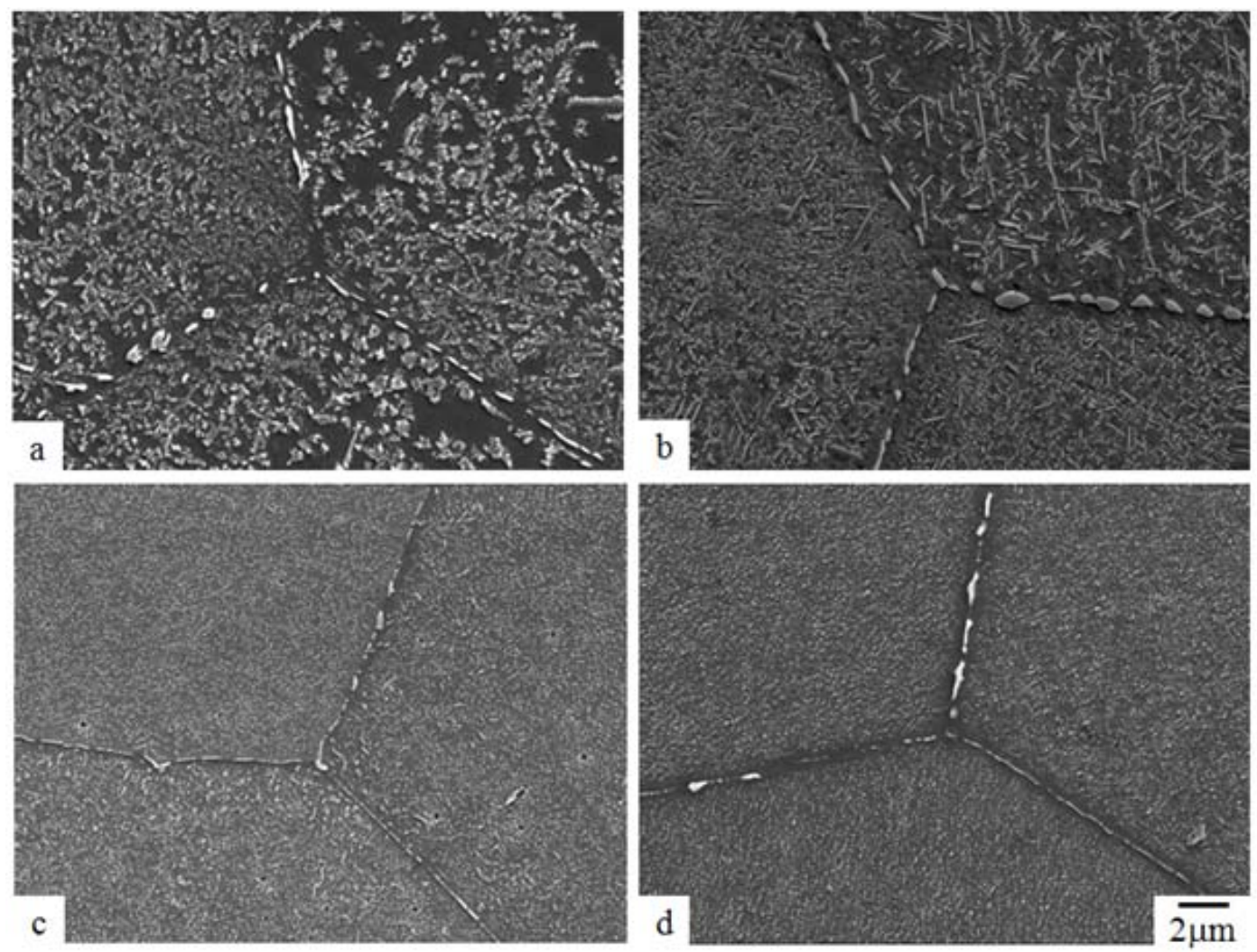

Fig. 4. Secondary electron images (SEIs) showing microstructures of base steel and Zr-doped steel that were aged at $973 \mathrm{~K}$ : (a) base steel, aged for $240 \mathrm{~h}$; (b) base steel, aged for $1200 \mathrm{~h}$; (c) Zr-doped steel, aged for $240 \mathrm{~h}$; (d) Zr-doped steel, aged for $1200 \mathrm{~h}$. 

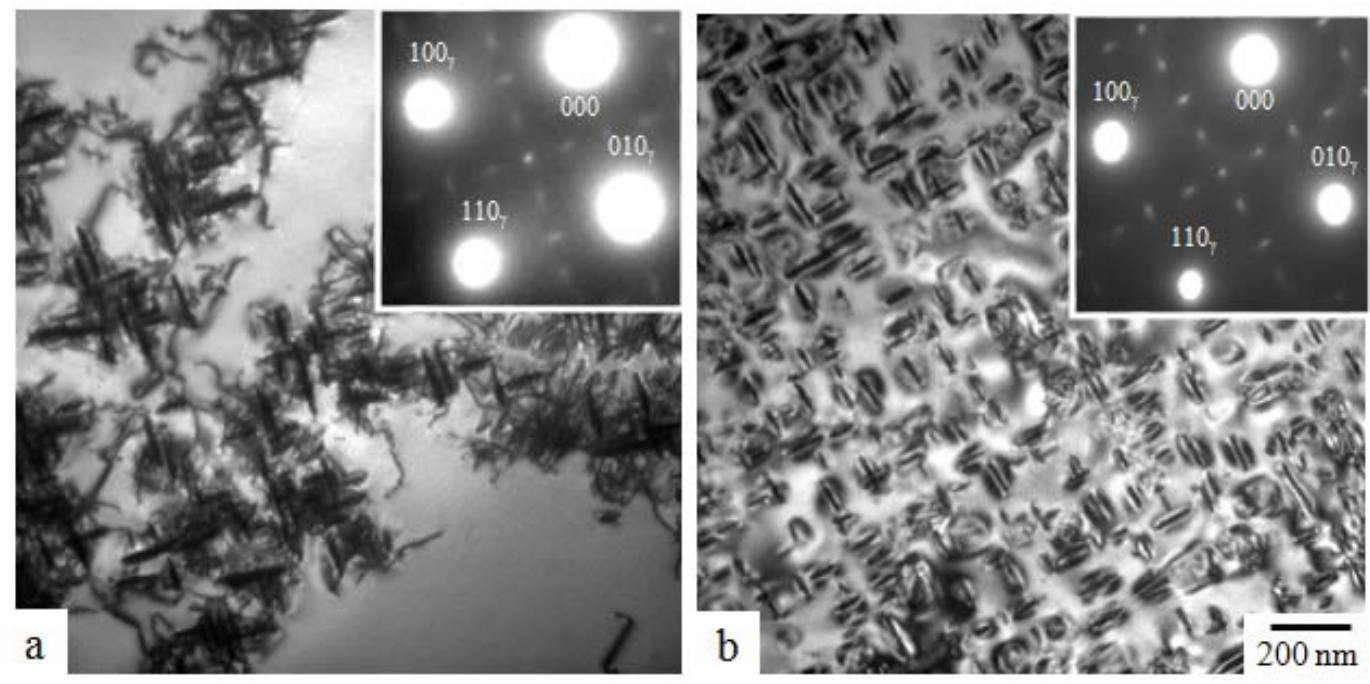

Fig. 5. (a) TEM bright field images showing the precipitates of "- $\mathrm{Ni}_{3} \mathrm{Nb}$ phase in -Fe matrix of the base steel aged at $973 \mathrm{~K}$ for $240 \mathrm{~h}$ and (b) the Zr-doped steel aged at $973 \mathrm{~K}$ for $1200 \mathrm{~h}$. 

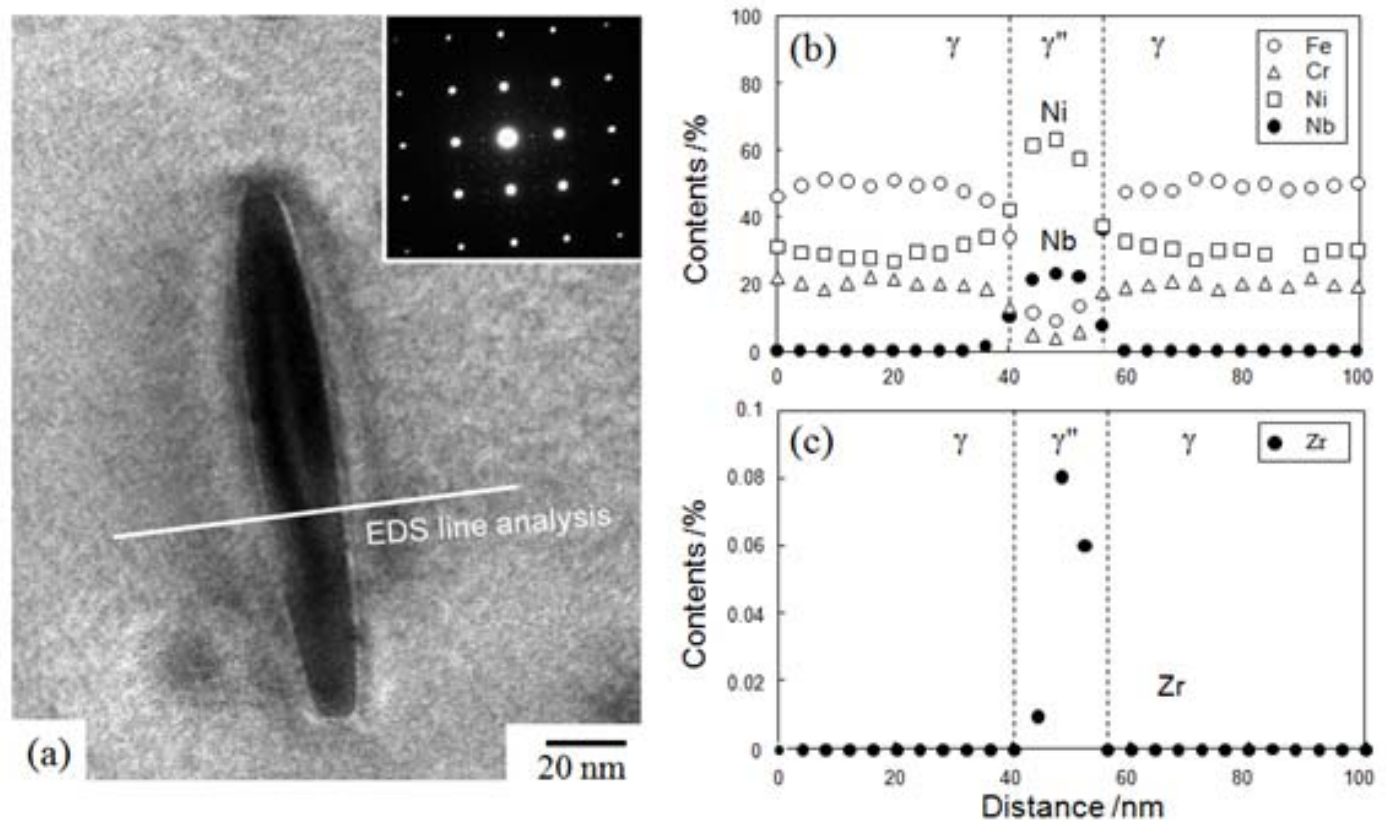

Fig. 6. (a) TEM bright field images showing the precipitate of "- $\mathrm{Ni}_{3} \mathrm{Nb}$ phase in -Fe matrix of the $\mathrm{Zr}$-doped steel aged at $973 \mathrm{~K}$ for $240 \mathrm{~h}$ and (b.c) composition line profiles along the corresponding line shown in the TEM image (a). 


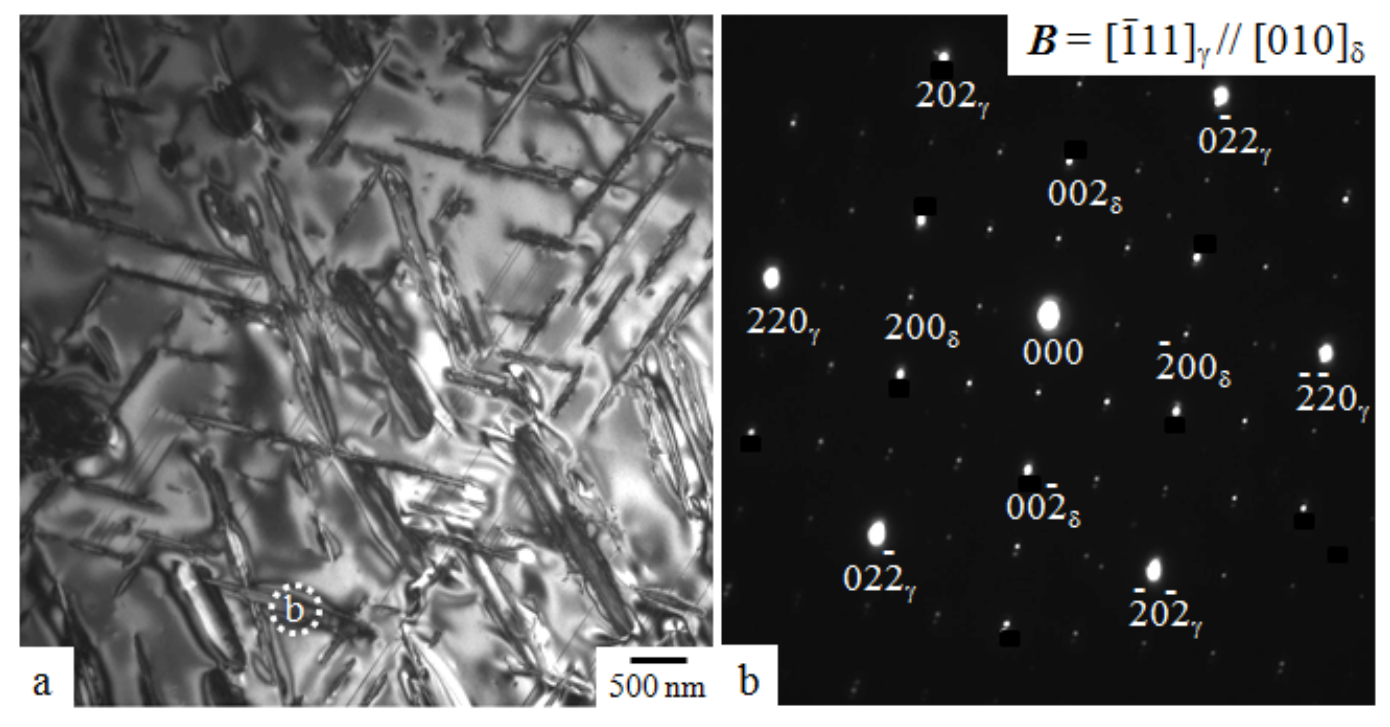

Fig. 7. (a) TEM bright field images showing the precipitates of $-\mathrm{Ni}_{3} \mathrm{Nb}$ phase in $-\mathrm{Fe}$ matrix of the base steel aged at $973 \mathrm{~K}$ for $3600 \mathrm{~h}$ and (b) selected area electron diffraction obtained from the corresponding region of (b) in the TEM image. 

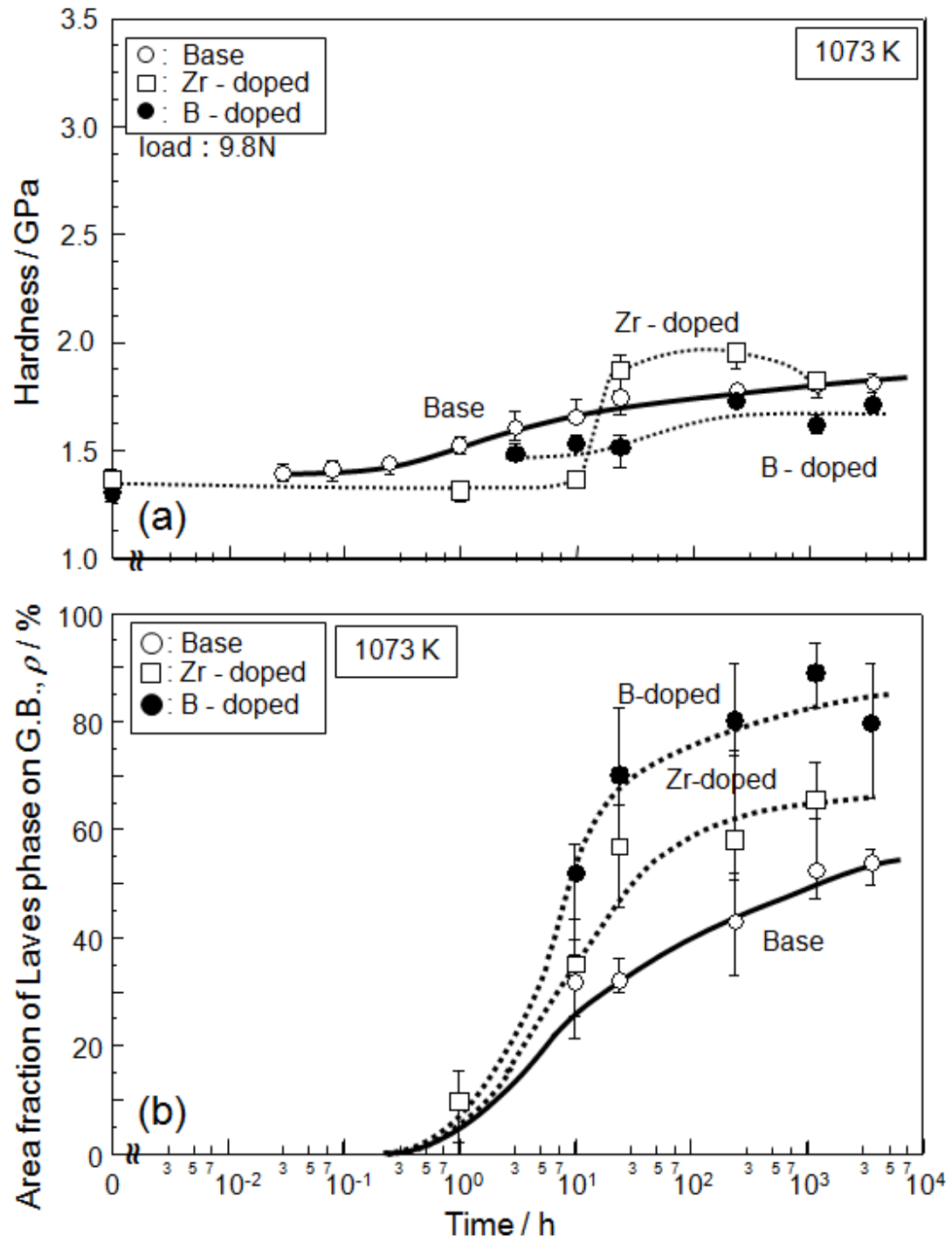

Fig. 8. Changes in (a) hardness of the grain interior and (b) area fraction of the Laves phase on grain boundaries ( ) with aging time at $1073 \mathrm{~K}$. 

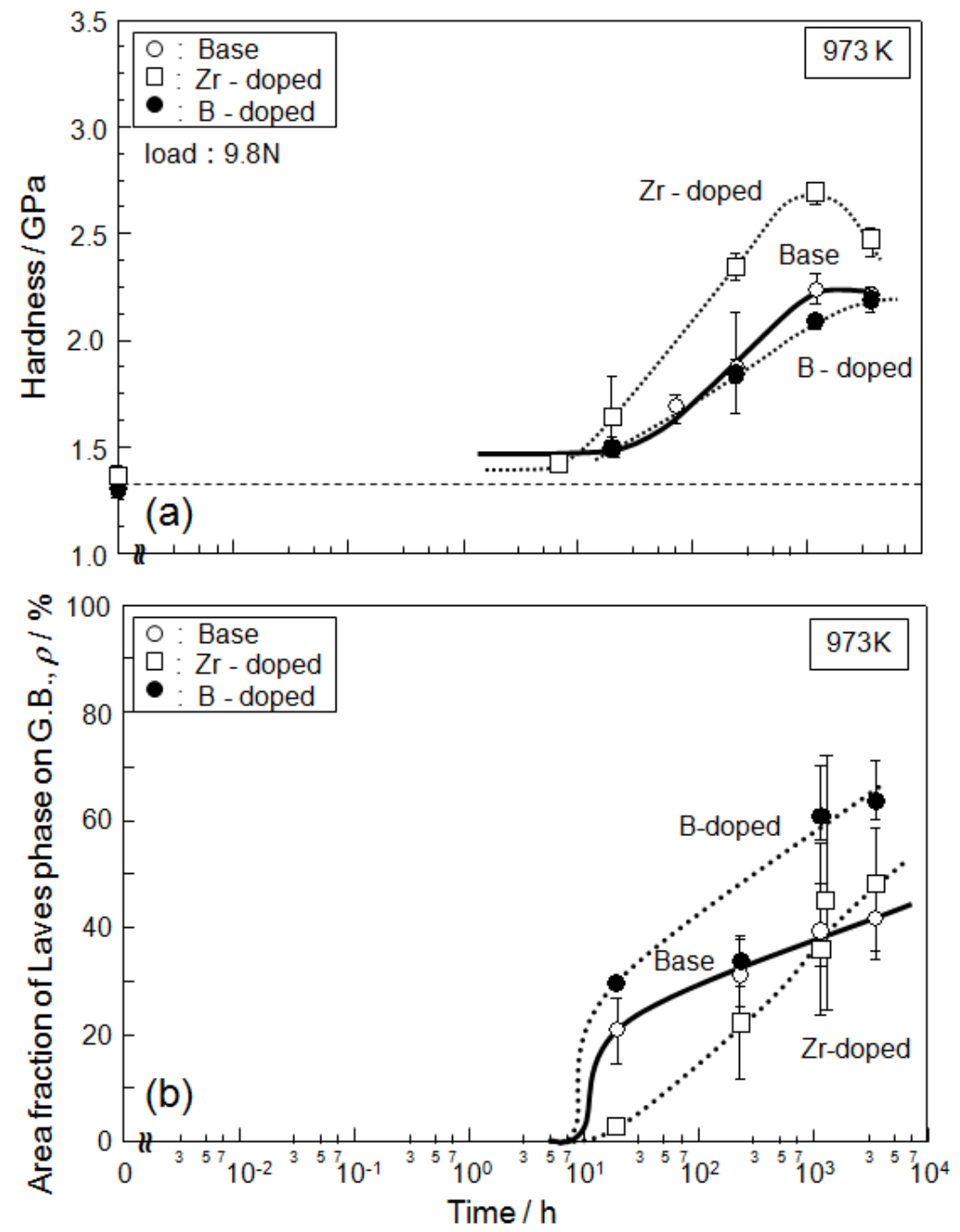

Fig. 9. Changes in (a) hardness of the grain interior and (b) with aging time at $973 \mathrm{~K}$. 


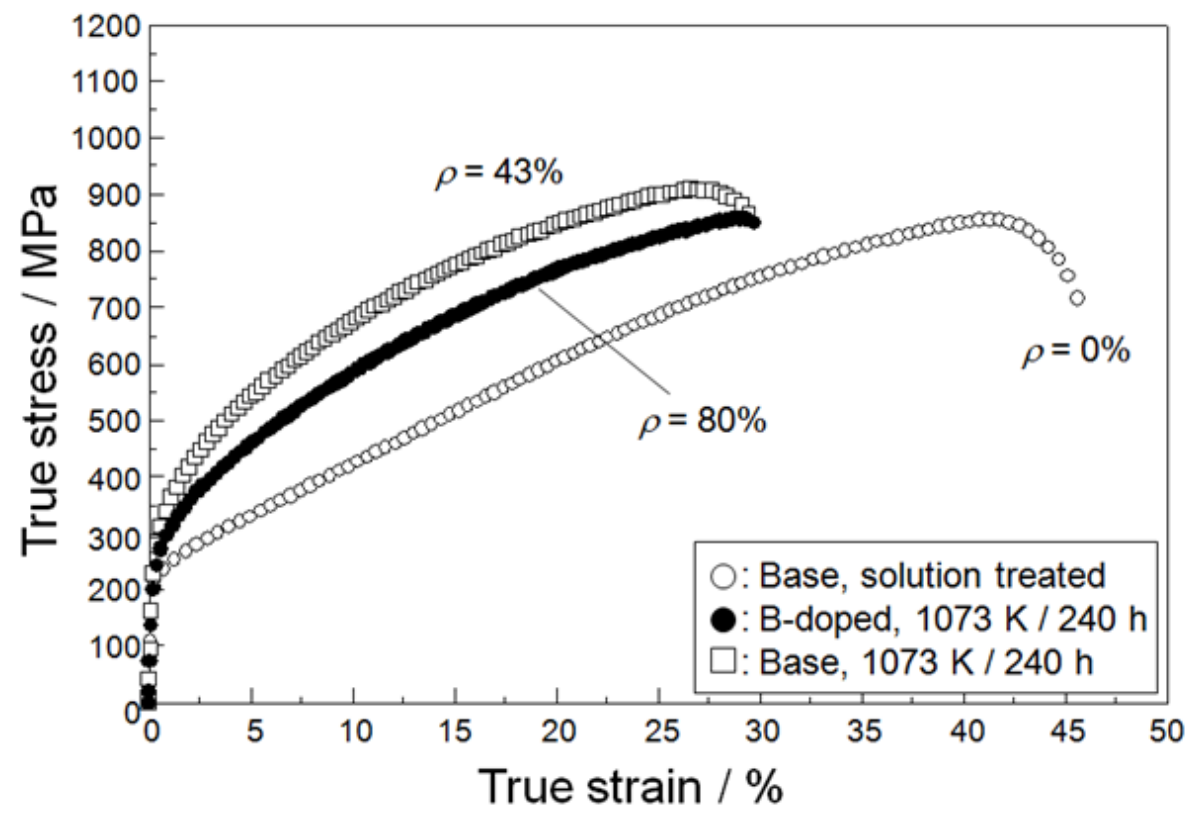

Fig. 10. True-stress-true-strain curves of $\mathrm{Fe}-20 \mathrm{Cr}-30 \mathrm{Ni}-2 \mathrm{Nb}$ steel specimens with various values of ( $=0$ : base steel solution, solution-treated; $=43 \%$ : base steel, aged at $1073 \mathrm{~K}$ for $240 \mathrm{~h}$; $=80 \%$ : B-doped steel, aged at $1073 \mathrm{~K}$ for $240 \mathrm{~h}$ ) at room temperature. 


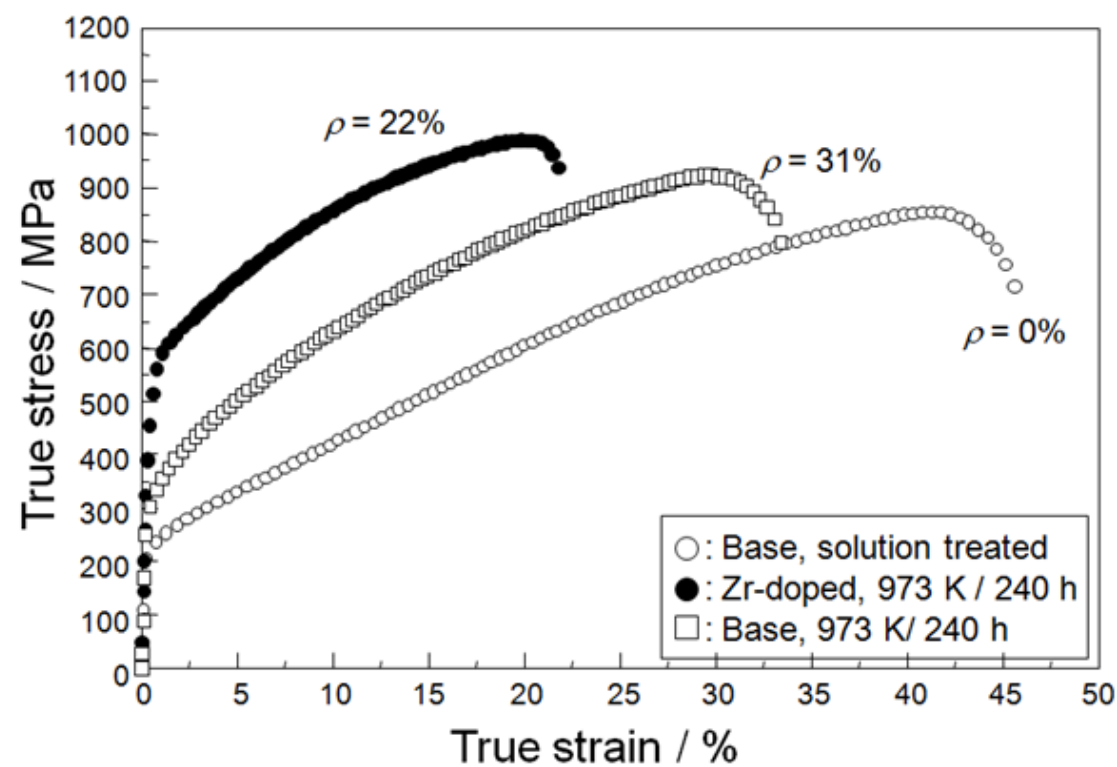

Fig. 11. True-stress-true-strain curves of $\mathrm{Fe}-20 \mathrm{Cr}-30 \mathrm{Ni}-2 \mathrm{Nb}$ steel specimens with low values of $(=0$ : base steel, solution-treated; $=22 \%$ : $\mathrm{Zr}$-doped steel, aged at $973 \mathrm{~K}$ for $240 \mathrm{~h} ;=31 \%$ : base steel, aged at $973 \mathrm{~K}$ for $240 \mathrm{~h}$ ) at room temperature. 


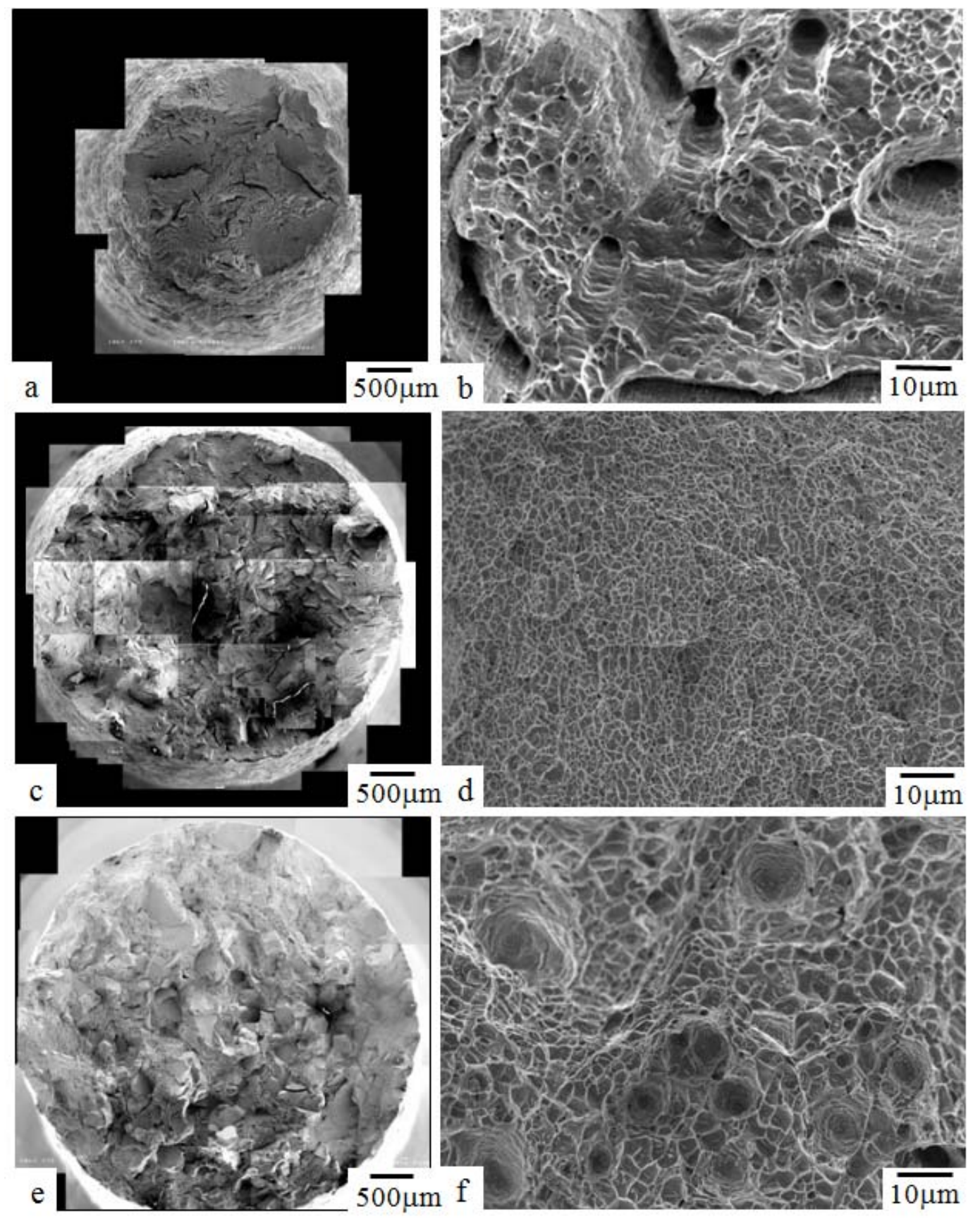

Fig. 12. Fracture surfaces of tensile-test specimens of $\mathrm{Fe}-20 \mathrm{Cr}-30 \mathrm{Ni}-2 \mathrm{Nb}$ steels with various values of $:(a, b)=0$ : base steel, solution-treated; $(c, d)=43 \%$ : base steel, aged at 1073 $\mathrm{K}$ for $240 \mathrm{~h}$; $(\mathrm{e}, \mathrm{f}) \quad=80 \%$ : B-doped steel, aged at $1073 \mathrm{~K}$ for $240 \mathrm{~h}$. 

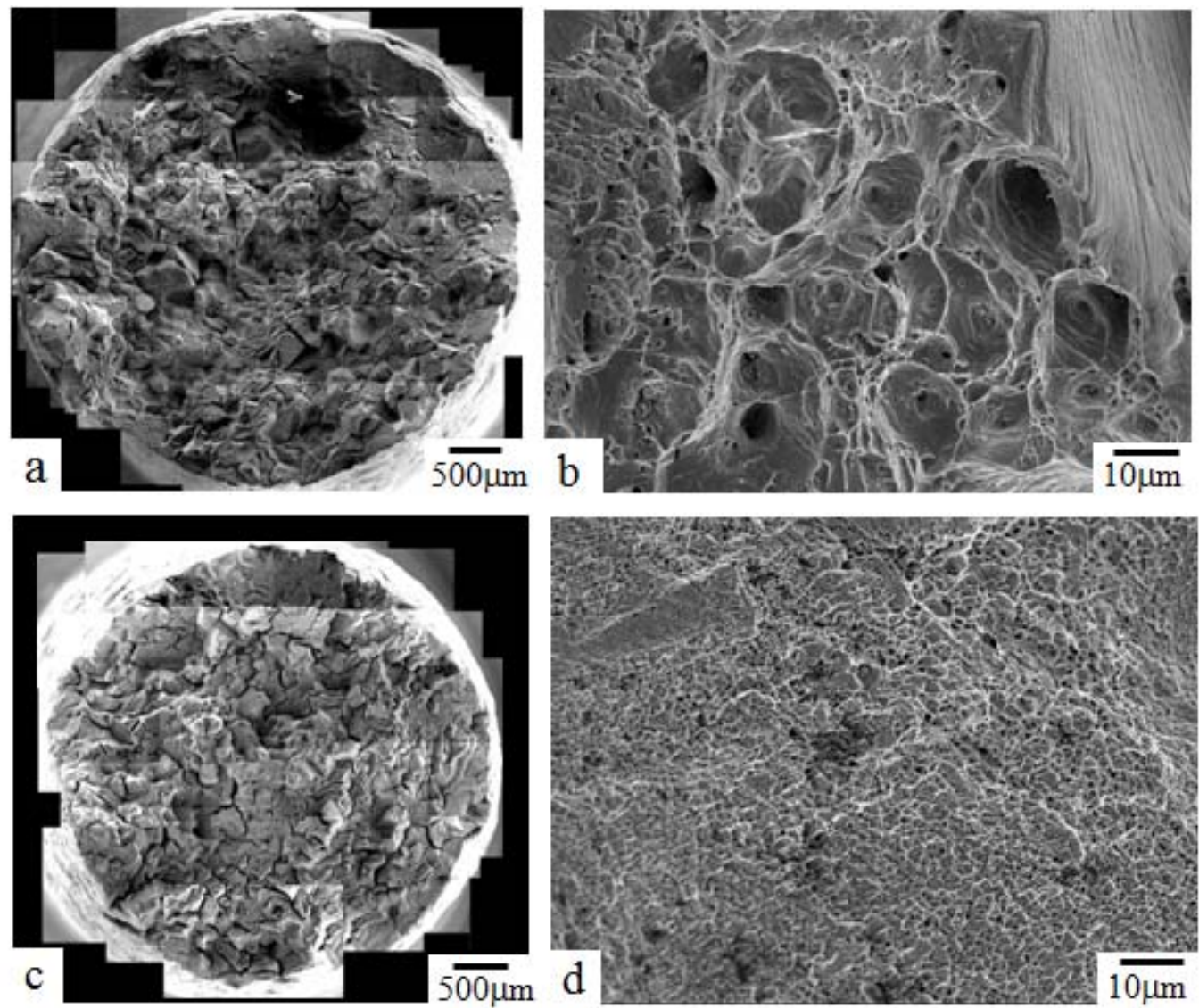

Fig. 13. Fracture surfaces of tensile test specimens of $\mathrm{Fe}-20 \mathrm{Cr}-30 \mathrm{Ni}-2 \mathrm{Nb}$ steels with low values of $:(a, b)=31 \%$ : base steel, aged at $973 \mathrm{~K}$ for $240 \mathrm{~h}$; (c, d) $=22 \%$ : Zr-doped steel, aged at $973 \mathrm{~K}$ for $240 \mathrm{~h}$. 

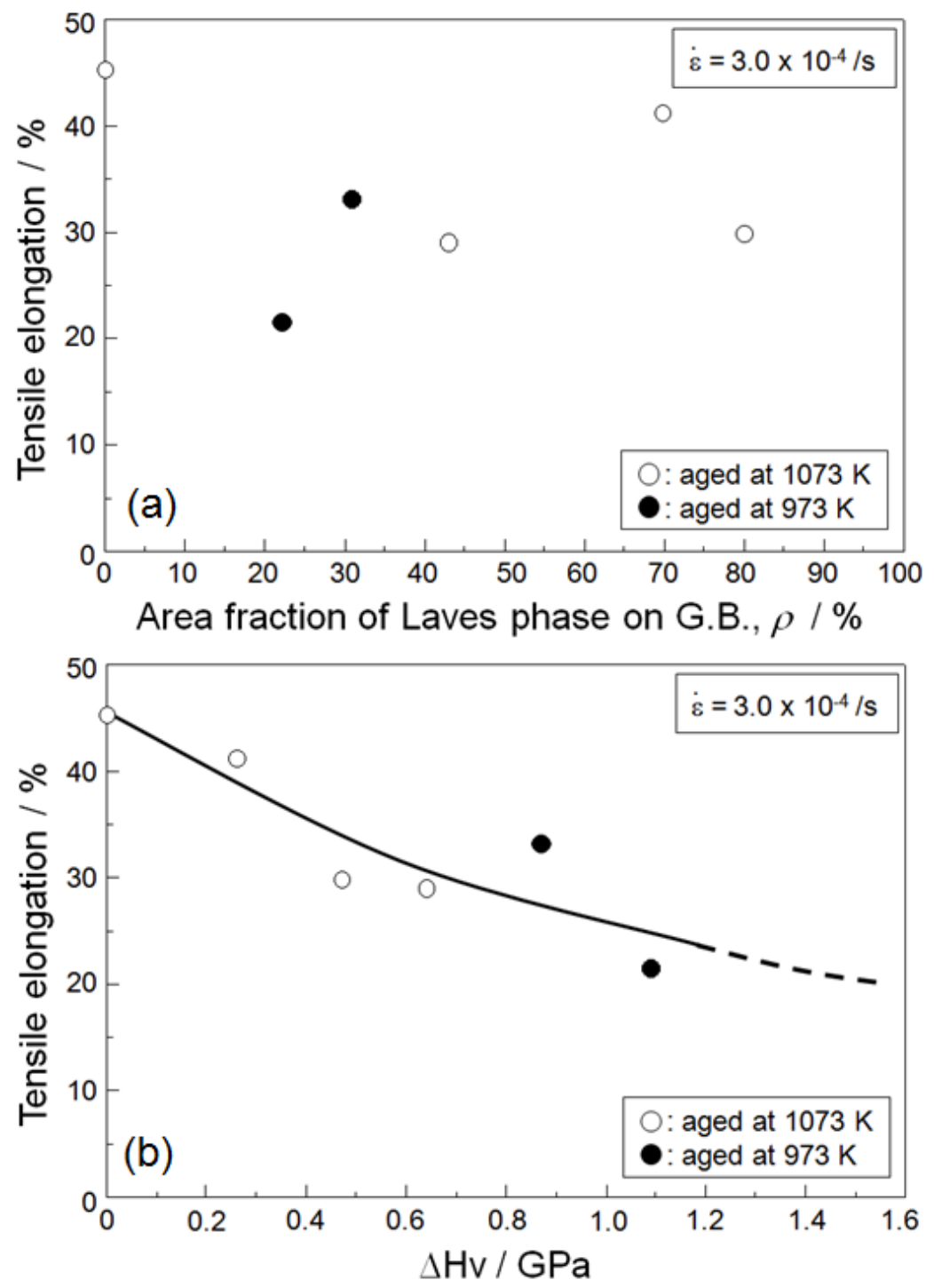

Fig. 14. Changes in tensile elongation as functions of (a) and (b) HV. 


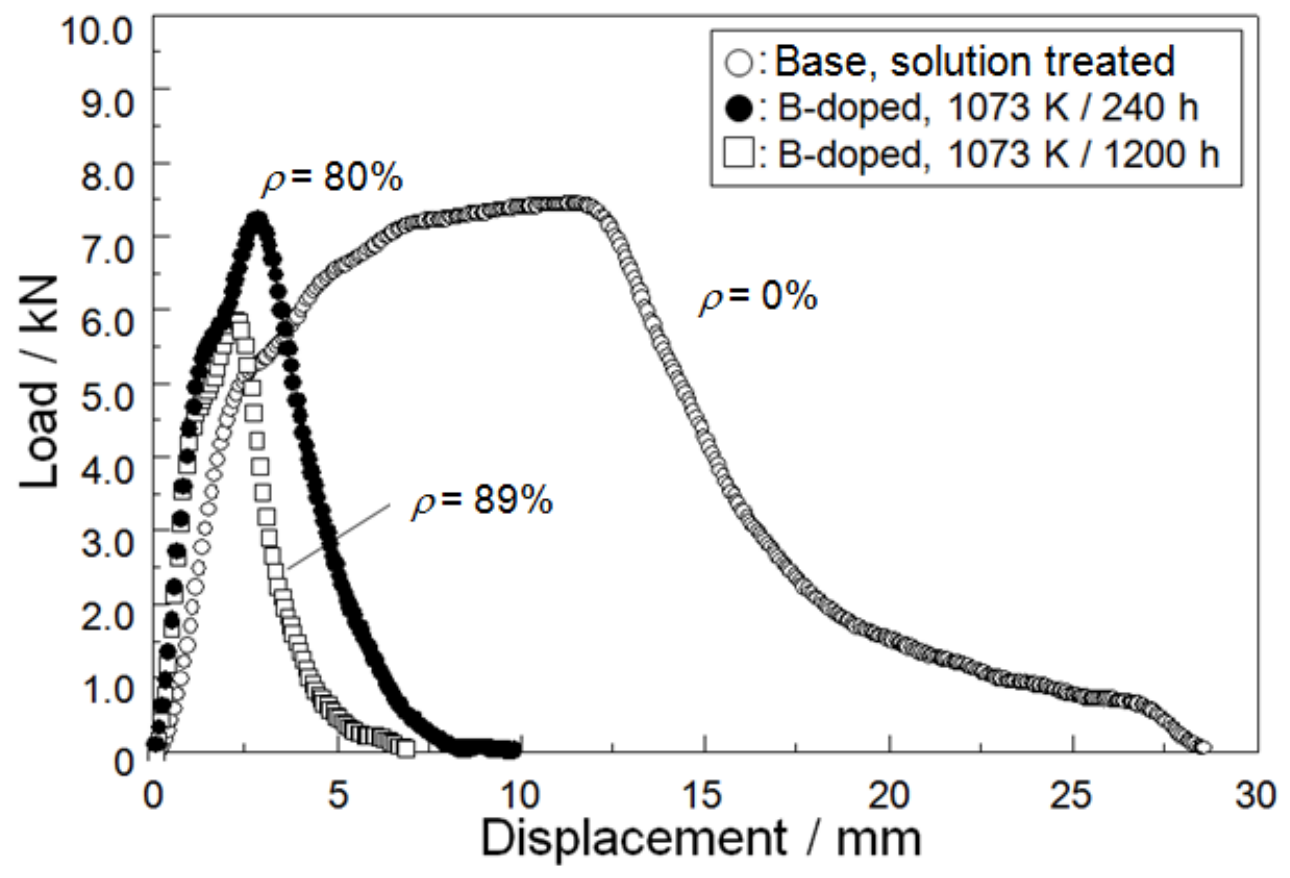

Fig. 15. Load-displacement curves of $\mathrm{Fe}-20 \mathrm{Cr}-30 \mathrm{Ni}-2 \mathrm{Nb}$ steel specimens with various values of $(=0$ : base steel, solution-treated; $=80 \%$ : B-doped steel, aged at $1073 \mathrm{~K}$ for $240 \mathrm{~h} ; \quad=89 \%$ : B-doped steel, aged at $1073 \mathrm{~K}$ for $1200 \mathrm{~h}$ ) at room temperature. These curves were obtained by Charpy impact tests. 

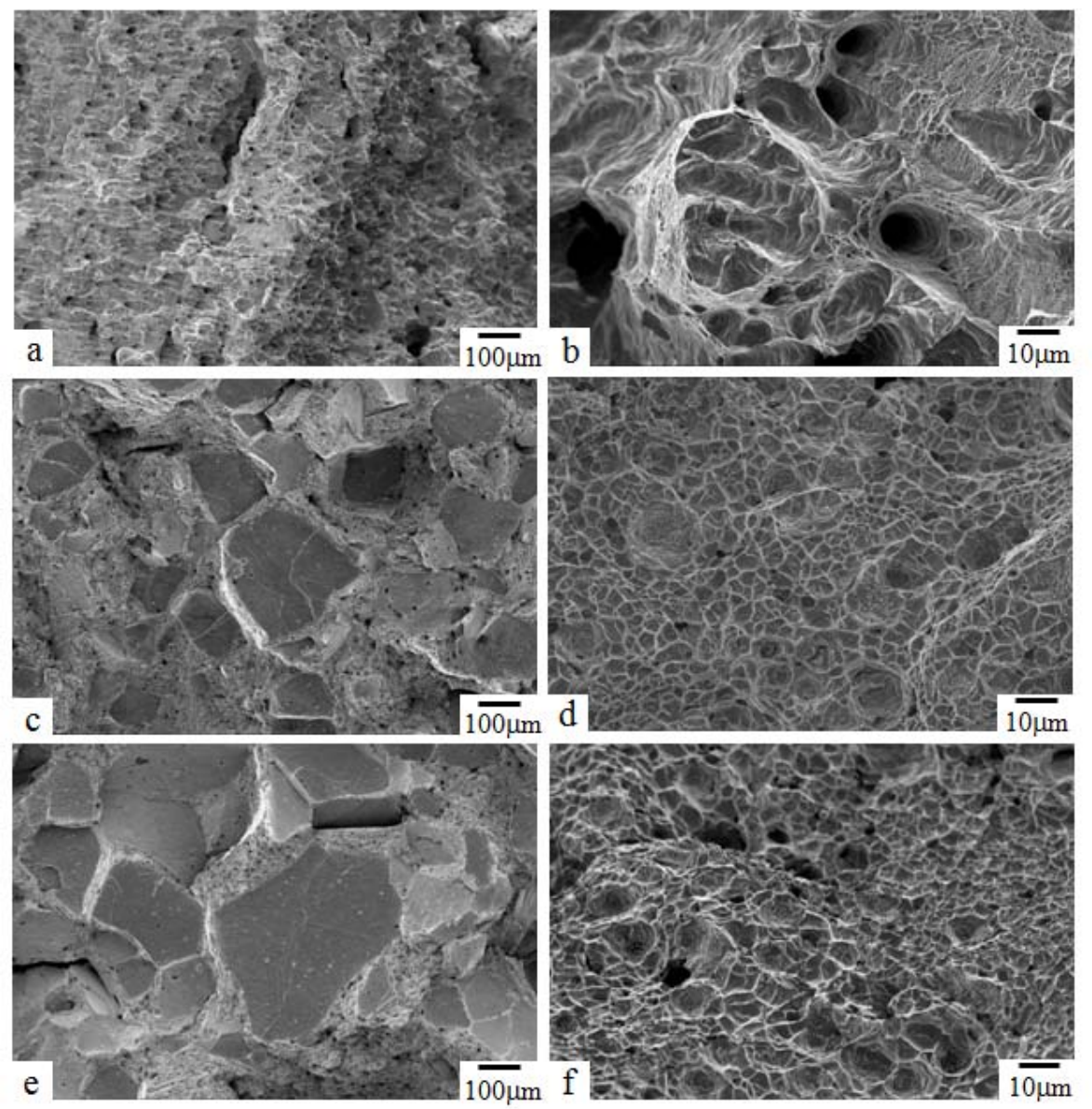

Fig. 16. Fracture surfaces of the Charpy impact test specimens of $\mathrm{Fe}-20 \mathrm{Cr}-30 \mathrm{Ni}-2 \mathrm{Nb}$ steels with various values of $:(a, b)=0$ : base steel, solution-treated; $(\mathrm{c}, \mathrm{d})=80 \%$ : B-doped steel, aged at $1073 \mathrm{~K}$ for $240 \mathrm{~h}$; (e, f) $=89 \%$ : B-doped steel, aged at $1073 \mathrm{~K}$ for $1200 \mathrm{~h}$. 

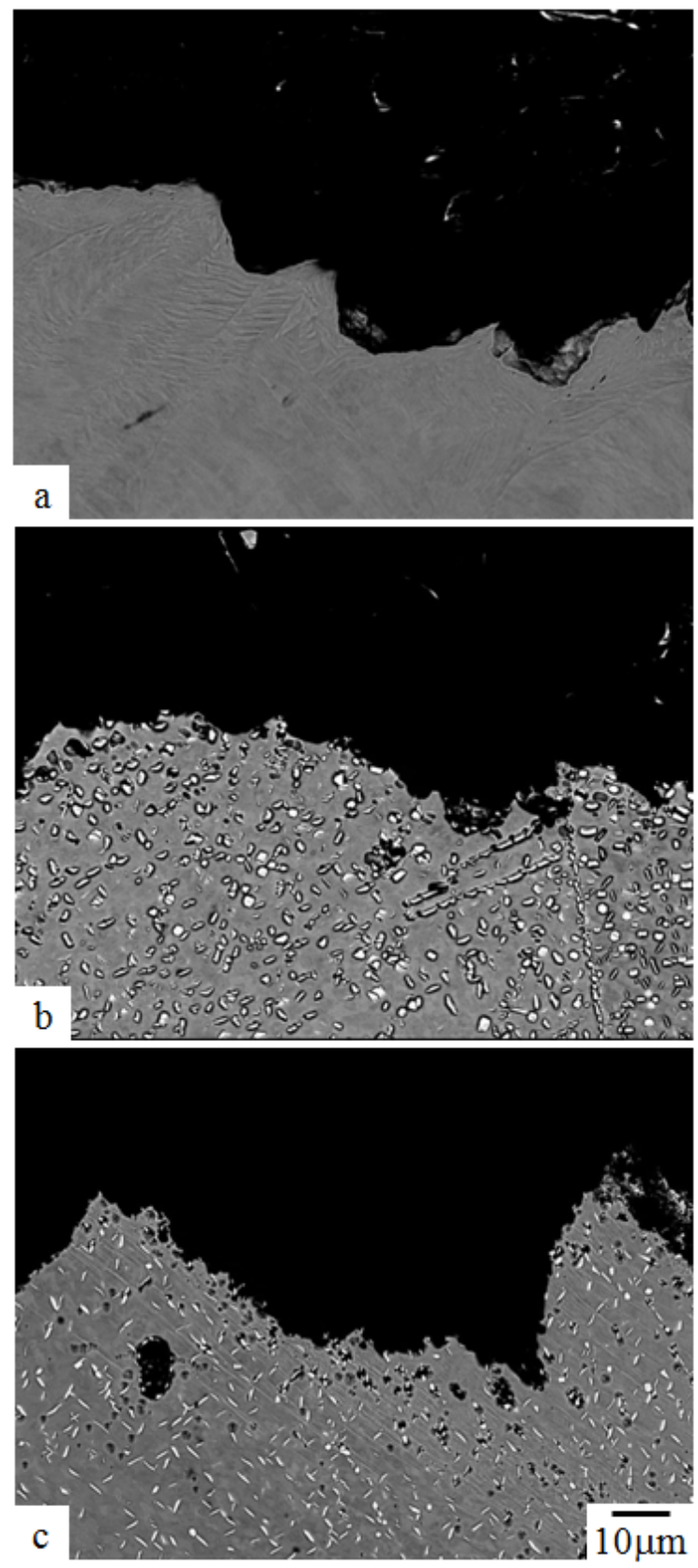

Fig. 17. BEIs showing the fracture region in the Charpy-impact-test specimens with various values of : (a) $=0$ : base steel, solution-treated; (b) $=80 \%$ : B-doped steel, aged at 1073 $\mathrm{K}$ for $240 \mathrm{~h}$; (c) $=89 \%$ : B-doped steel, aged at $1073 \mathrm{~K}$ for $1200 \mathrm{~h}$. 


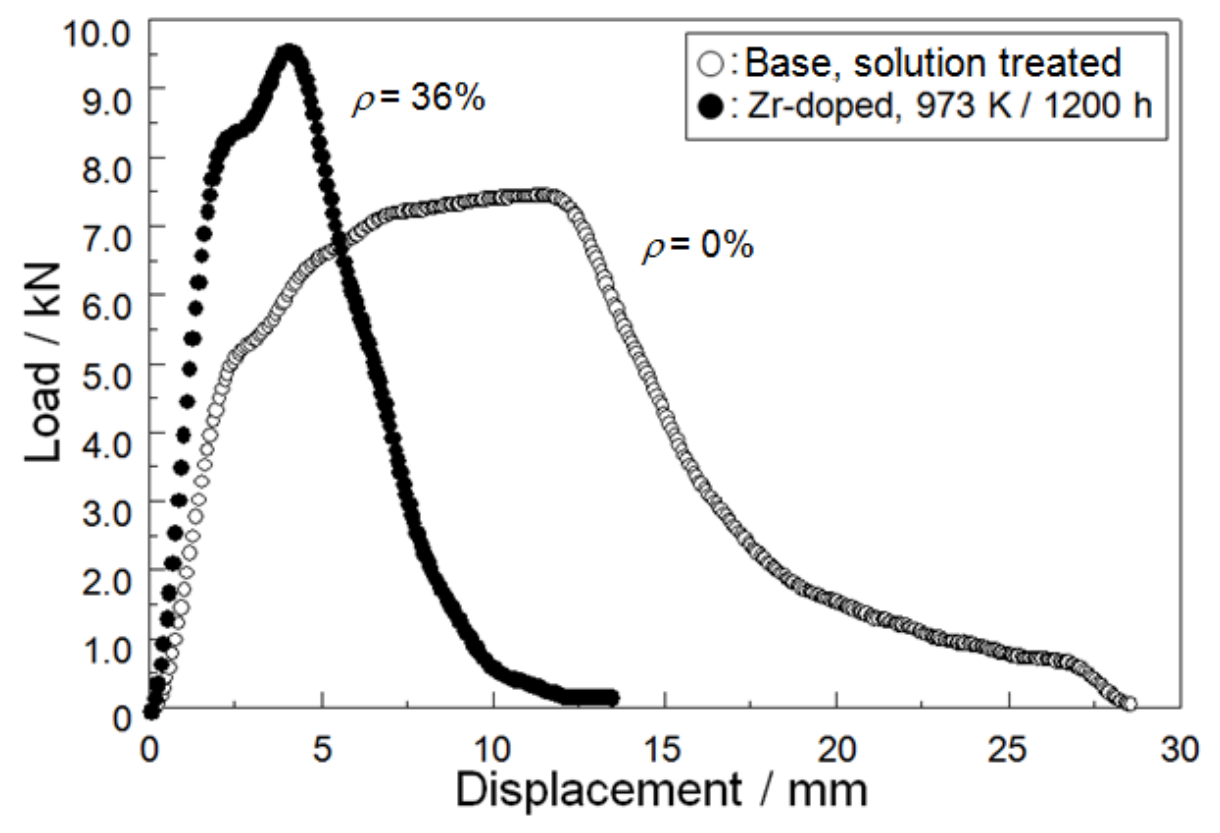

Fig. 18. Load-displacement curves of $\mathrm{Fe}-20 \mathrm{Cr}-30 \mathrm{Ni}-2 \mathrm{Nb}$ steel specimens with low values of ( $=0$ : base steel, solution-treated; $\quad=36 \%$ : Zr-doped steel, aged at $973 \mathrm{~K}$ for $1200 \mathrm{~h}$ ) at room temperature. These curves were obtained by Charpy impact tests. 

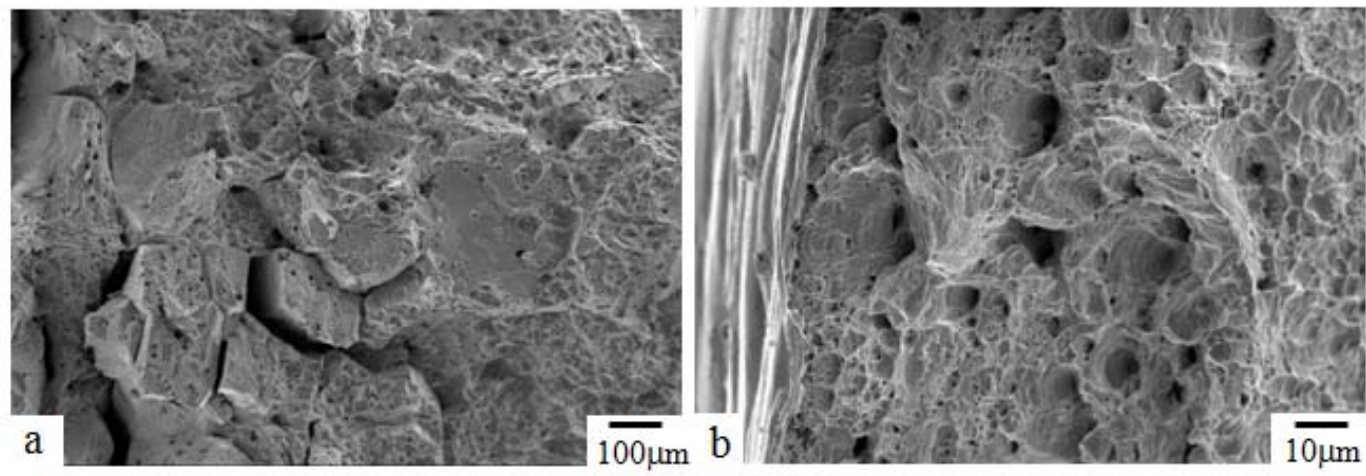

Fig. 19. Fracture surfaces of the Charpy impact test specimens of $\mathrm{Fe}-20 \mathrm{Cr}-30 \mathrm{Ni}-2 \mathrm{Nb}$ steel with $=36 \%$ (Zr-doped steel, aged at $973 \mathrm{~K}$ for $1200 \mathrm{~h})$. 

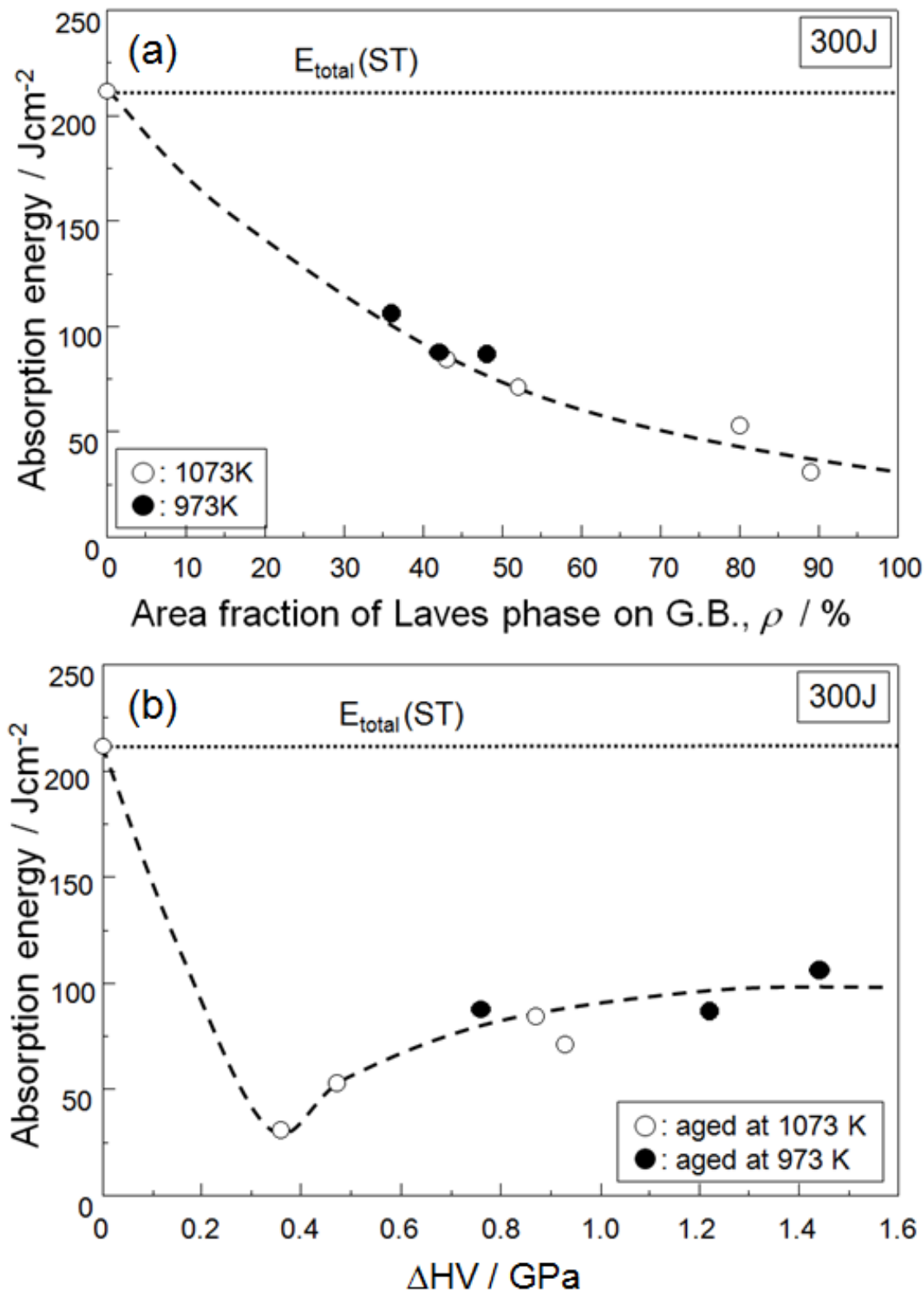

Fig. 20. Changes in absorption energy measured by the Charpy impact test as functions of (a) and (b) HV. 


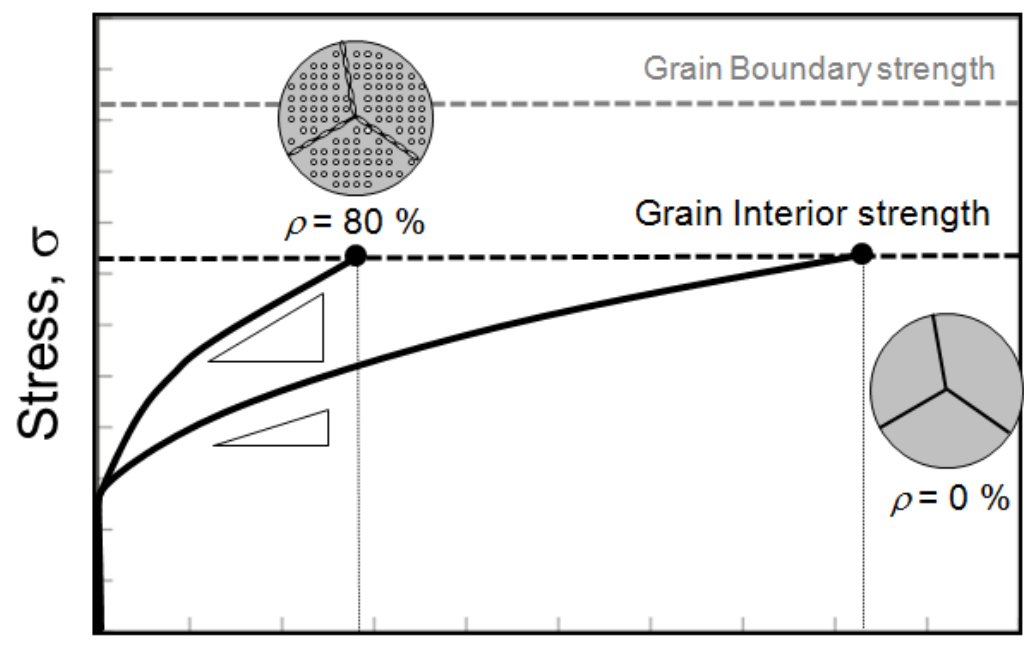

Strain, $\varepsilon$

Fig. 21. Schematic illustration showing the reduction in tensile ductility by precipitates of the Laves phase in the $-\mathrm{Fe}$ matrix. 


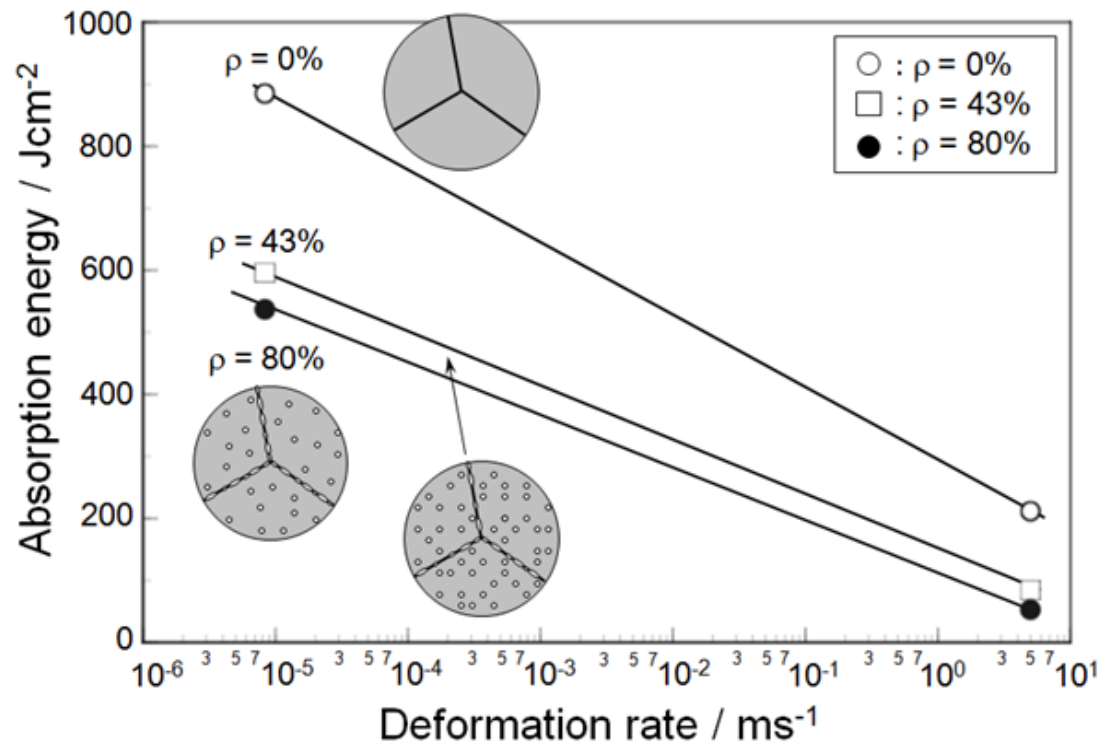

Fig. 21. Absorption energies of the specimens with $=0,43$, and $80 \%$ at different deformation rates of $5.0 \mathrm{~m} / \mathrm{s}$ (Charpy impact test) and $8.6 \times 10^{-6} \mathrm{~m} / \mathrm{s}$ (tensile test). 